\title{
Differential unroofing within the Central Metasedimentary Belt of the Grenville Orogen: constraints from ${ }^{40} \mathrm{Ar} /{ }^{39} \mathrm{Ar}$ thermochronology*
}

\author{
Michael A. Cosca ${ }^{1}{ }^{* *}$, Eric J. Essene ${ }^{1}$, Michael J. Kunk ${ }^{2}$, and John F. Sutter ${ }^{2}$ \\ ${ }^{1}$ Department of Geological Sciences, University of Michigan, Ann Arbor, MI 48109-1063, USA \\ ${ }^{2}$ United States Geological Survey, Reston, VA 22092, USA
}

Received May 10, 1991/Accepted August 27, 1991

\begin{abstract}
An ${ }^{40} \mathrm{Ar} /{ }^{39} \mathrm{Ar}$ thermochronological investigation of upper greenschist to granulite facies gneiss, amphibolite and marble was conducted in the Central Metasedimentary Belt (CMB), Ontario, to constrain its cooling history. Incremental ${ }^{40} \mathrm{Ar} /{ }^{39} \mathrm{Ar}$ release spectra indicate that substantial differential unroofing occurred in the CMB between $\sim 1000$ and $\sim 600$ Ma. A consistent pattern of significantly older hornblende and phlogopite ${ }^{40} \mathrm{Ar} /{ }^{3} \mathrm{Ar}$ cooling ages on the southeast sides of major northeast striking shear zones is interpreted to reflect late displacement due to extensional deformation. Variations in hornblende ${ }^{40} \mathrm{Ar} /{ }^{39} \mathrm{Ar}$ age plateaus exceeding $200 \mathrm{Ma}$ occur over distances less than $50 \mathrm{~km}$ with major age discontinuities occurring across the Robertson Lake shear zone and the Sharbot Lake mylonite zone which separate the Sharbot Lake terrane from the Elzevir and Frontenac terranes. Extensional displacements of up to $14 \mathrm{~km}$ are inferred between the Frontenac and Elzevir terranes of the CMB. No evidence for significant post argon-closure vertical displacement is indicated in the vicinity of the Perth Road mylonite within the Frontenac terrane. Variations of nearly $100 \mathrm{Ma}$ in phlogopite ${ }^{40} \mathrm{Ar} /{ }^{39} \mathrm{Ar}$ plateau ages occur in undeformed marble on either side of the Bancroft Shear Zone. Phlogopites from sheared and mylonitized marble within the shear zone yield ${ }^{40} \mathrm{Ar} /{ }^{39} \mathrm{Ar}$ diffusional loss profiles, but have older geologically meaningless ages thought to reflect incorporation of excess argon. By $\sim 900 \mathrm{Ma}$, southeast directed extension was occurring throughout the CMB, possibly initiated along previous zones of compressional shearing. An easterly migration of active zones of extension is inferred, possibly related to an earlier, overall easterly migration of active zones of regional thrusting and easterly migration of an ancient subduction zone. The duration of extensional shearing is not well constrained, but must have ceased before $\sim 600 \mathrm{Ma}$ as required by the deposition of over-
\end{abstract}

\footnotetext{
*Contribution No. 481 from the Mineralogical Laboratory, University of Michigan

** Current address: Université de Lausanne, Institut de Minéralogie, BFSH-2, CH-1015 Lausanne, Switzerland

offprint requests to: M.A. Cosca
}

lying undeformed Cambrian and/or Ordovician sedimentary rocks.

\section{Introduction}

The Grenville Orogen is a regional metamorphic terrane dominated by rocks of high metamorphic grade with $\mathrm{K} /$ Ar ages of $\sim 1.2-1.0 \mathrm{Ga}$ (e.g. Stockwell 1964). Exposed roughly at sea level over an area approximately $1900 \mathrm{~km}$ in length and $400 \mathrm{~km}$ in width (Moore 1986; Woussen et al. 1986), the Grenville Orogen is the root of an ancient mountain belt which may have tectonic affinities with the present day Himalaya (e.g. Dewey and Burke 1973; Baer 1976; Davidson et al. 1982; Windley 1986; Hanmer 1988; van der Pluijm and Carlson 1989). In southeastern Ontario, the Grenville Orogen is subdivided into two NESW trending, regionally metamorphosed belts, the Central Gneiss Belt (CGB) and the Central Metasedimentary Belt (CMB), which are separated by a tectonic boundary, the Central Metasedimentary Belt Boundary Zone (CMBBZ) (Wynne-Edwards 1972; Davidson 1984; Fig. 1). In an earlier investigation Cosca et al. (1991a) detailed the regional cooling, uplift, and erosion history of the Grenville Orogen exposed in southeastern Ontario based on ${ }^{40} \mathrm{Ar} /{ }^{39} \mathrm{Ar}$ results from 57 mineral separates of hornblende, muscovite, biotite and microcline. These data indicate that the onset of cooling through argon closure of the CMB was non-uniform, as revealed by differences of nearly $200 \mathrm{Ma}$ in ${ }^{40} \mathrm{Ar} /{ }^{39} \mathrm{Ar}$ hornblende cooling ages, and that significant age variations occur across large shear zones separating the four terranes of the CMB. Cosca et al. (1991a) interpreted the variation in hornblende ${ }^{40} \mathrm{Ar} /{ }^{39} \mathrm{Ar}$ cooling ages as a consequence of late tectonic differential uplift due to extensional tectonics. However, the amount of isotopic data in the CMB was insufficient to document a convincing case for late offsets along certain major shears.

The purpose of this investigation is to present further ${ }^{40} \mathrm{Ar} /{ }^{39} \mathrm{Ar}$ data from the four terranes of the CMB, the 


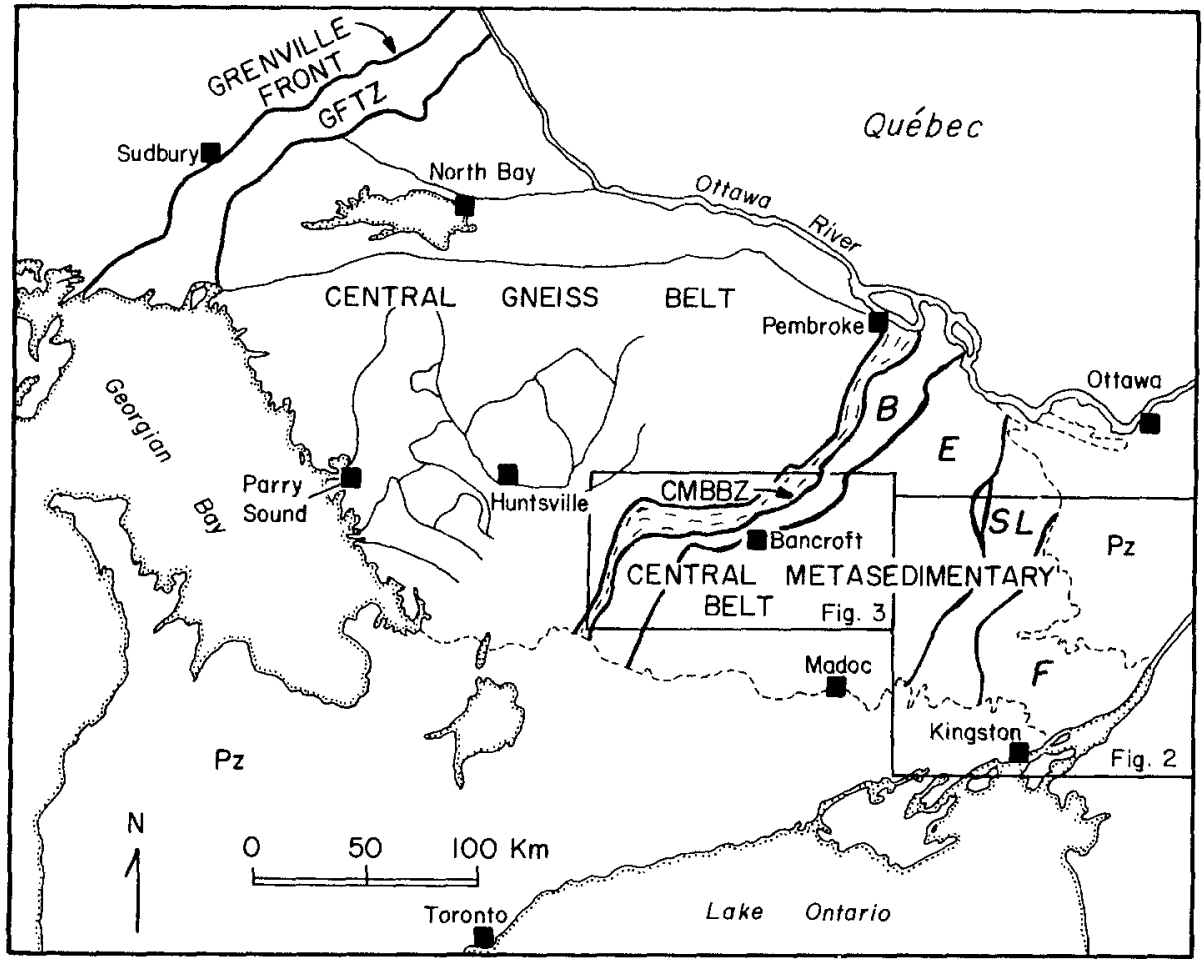

Fig. 1. Location map of the Grenville Orogen in Ontario including tectonic boundaries and locations of Figs 2 and 3. GFTZ, Grenville Front Tectonic Zone; $C M B B Z$, Central

Metasedimentary Belt Boundary Zone; $B$, Bancroft terrane; $E$, Elzevir terrane; $S L$, Sharbot Lake terrane; $F$, Frontenac terrane; $P z$, Paleozoic cover
Frontenac, the Elzevir, the Sharbot Lake, and the Bancroft terranes (cf. Wynne-Edwards 1972; Moore 1982; Davidson 1986; Easton 1989), in order to evaluate more comprehensively the pattern of ${ }^{40} \mathrm{Ar} /{ }^{39} \mathrm{Ar}$ cooling ages in and between these terranes and to determine their importance in reconstructing the tectonic evolution of the CMB. The term terrane as used throughout this paper is consistent with existing terminology for the Grenville Orogen but does not necessarily imply an exotic or allochthonous origin.

Hornblende-bearing gneisses and amphibolites were collected for ${ }^{40} \mathrm{Ar} /{ }^{39} \mathrm{Ar}$ analysis from both sides of the boundary zones separating the Frontenac, the Sharbot Lake, and the Elzevir terranes in order better to constrain the timing and sense of motion across these boundaries. Similarly, samples were collected on both sides of the Perth Road mylonite zone (cf. Carmichael et al. 1987; Fig. 2), in an attempt to elucidate the timing and sense of motion of mylonites entirely within the Frontenac terrane. In addition, phlogopite-bearing marbles were sampled both inside and outside the Bancroft shear zone, which separates the Bancroft and Elzevir terranes, in order to place time constraints upon the duration of active shearing inferred from structural observations in this area (Hanmer 1988; van der Pluijm and Carlson 1989; Carlson et al. 1990).

\section{Geological summary}

\section{Central Gneiss Belt}

The Grenville Orogen in Ontario is lithologically diverse and variably metamorphosed from greenschist to granulite facies. Regional metamorphic conditions inferred from mineral equilibra vary from $4 \mathrm{kbar}, 400^{\circ} \mathrm{C}$, to $11 \mathrm{kbar}, 800^{\circ} \mathrm{C}$ (Anovitz and Essene 1990). The CGB, parts of which record the highest metamorphic pressures and temperatures, is characterized by layered gneisses and amphibolites that were metamorphosed under upper amphibolite to granulite facies conditions. The CGB contains a network of ductile shear zones, some continuously exposed for at least tens of kilometers, that separate domains and subdomains with distinct lithotectonic characteristics (Davidson 1984). These domains have been interpreted to represent a series of imbricate crustal slices that were assembled during orogenesis (Culshaw et al. 1983; Davidson 1984). The shear zones separating the domains contain rotated porphyroclasts and stretching lineations that indicate low angle ductile thrusting toward the northwest (Davidson 1984). The timing of thrustrelated displacement has been interpreted from $\mathrm{U} / \mathrm{Pb}$ zircon ages of syntectonic pegmatites intruded into the shear zones. van Breemen et al. (1986) reported $\mathrm{U} / \mathrm{Pb}$ zircon ages of 1121 and $1159 \mathrm{Ma}$ from zircons in different shear zones of the most deeply buried Parry Sound domain, near the town of Parry Sound, Ontario. To the east, a $\mathrm{U} / \mathrm{Pb}$ zircon age of $1103 \mathrm{Ma}$ has been determined from a syntectonic pegmatite that cuts the deformation fabric of rocks structurally overlapping the Parry Sound domain (van Breemen and Davidson 1990). The amount of displacement along these shear zones is unknown. Within the precision of geobarometry $( \pm 1 \mathrm{kbar})$, Moecher et al. (1988) and Anovitz and Essene (1990) found no significant variations in metamorphic pressures across most of the major shear zones in the CGB mapped by Davidson (1984).

\section{Central Metasedimentary Belt Boundary Zone}

The CMBBZ (Fig. 1) is characterized by intensely tectonized and recrystallized lithologies, commonly marbles and marble breccias, that contain disrupted layers of gneiss. Within the CMBBZ several alternating tonalitic and syenitic thrust sheets have been identified containing shear sense indicators consistent with a dominant northwest vergence along several ductile thrust sheets (Hanmer and Ciesielski 1984; Hanmer et al. 1985; Hanmer 1988). Thrusting appears to have been accommodated along less competent metapelite and marble layers and in some places is out of sequence (Hanmer 1988). Near the Ontario/Quebec border zircons from the 
CMBBZ yield U/Pb ages of $\sim 1140 \mathrm{Ma}$ (McEachern et al. 1990) and combined with field observations indicate that thrusting within the entire CMBBZ may have occurred at $\sim 1140$ m.y. Re-imbrication of the thrust zone occurred at $1060 \mathrm{Ma}$ as determined from $\mathrm{U} / \mathrm{Pb}$ zircon ages from syntectonic pegmatite and granite (van Breemen and Hanmer 1986) and on sphenes from nearby marbles (Mezger, pers. comm, 1991). Minor thrusting apparently continued in the $\mathrm{CMBBZ}$ as late as $1030 \mathrm{Ma}$ as evidenced by $\mathrm{U} / \mathrm{Pb}$ zircon ages from late syntectonic pegmatites (van Breemen and Hanmer 1986). Extensional shear zones cut across the entire thrust sequence in the CMBBZ (Hanmer 1988; van der Pluijm and Carlson 1989; Carlson et al. 1990).

\section{Central Metasedimentary Belt}

The CMB contains a variety of metasediments, metavolcanic and metaintrusive rocks metamorphosed from the upper greenschist to the granulite facies (Carmichael et al. 1978; Anovitz and Essene 1990). Rocks of lowest metamorphic grade occur in the "Hastings metamorphic low" (Carmichael et al. 1978) centered about Madoc. From Madoc, upper amphibolite to granulite facies assemblages occur in rocks to the northwest near Bancroft and to the southeast toward the St. Lawrence River. The time of the peak of metamorphism in the CMB has been estimated to vary from 1170 to $1020 \mathrm{Ma}$ based on $\mathrm{U} / \mathrm{Pb}$ ages of sphenes, garnets and monazites that are inferred to be growth, rather than cooling ages (Mezger et al. 1990).

\section{Shear zones of the Central Metasedimentary Belt}

The boundaries separating the constituent terranes of the CMB are often marked by zones of high strain or changes in metamorphic grade (e.g. Davidson 1986; Easton 1989). Highly strained zones associated with local and regional shearing are also present within the terranes (e.g. Ayres et al. 1971; Carmichael et al. 1987; Easton 1988). Field relationships from some of the larger shear zones suggest the Bancroft shear zone has an average southeasterly dip of about $30^{\circ}$ (Carlson et al. 1990), the Robertson Lake Mylonite a southeast dip of about $30^{\circ}$ (Easton 1988), and the Sharbot Lake mylonite a southeast dip of 60 to $70^{\circ}$ (Easton 1988). The shear zones have a southeast plunging stretching lineation, however the sense of motion along these often ultramylonitic zones of deformation is difficult to determine. In the Bancroft terrane numerous northwest-directed shear sense indicators have been observed (Easton and Bartlett 1984; Davidson 1986), but later, southeastdirected extensional shear sense indicators have also been observed (Carlson et al. 1990). The sense of displacement along the other large shear zones of the CMB is less clear. Where observed the field data are equivocal, as kinematic indicators are often obscured by intense deformation. The nature and significance of these shear zones is only beginning to become understood, but almost certainly they contain important geological clues necessary for reconstructing the tectonic evolution of the CMB and the Grenville Orogen.

\section{Bancroft terrane}

The Bancroft terrane (Fig. 1) runs roughly parallel to the CMBBZ. It consists mainly of marbles and marble breccias with nephelinebearing gneisses and other silica-undersaturated plutonic rocks occurring as sheets or as clasts within the marbles (Davidson 1986; Hanmer 1988). Metamorphic conditions recorded in the Bancroft terrane are middle to upper amphibolite facies (Anovitz and Essene 1990). The Bancroft terrane has been interpreted to be part of the same northwest-directed thrust-nappe complex as observed in the CGB (Easton and Bartlett 1984; Davidson 1986). Shear sense indicators consisting of S-C fabrics, fold closures and stretching lineations consistent with late extension are developed in the Bancroft terrane (Carlson et al. 1990). The boundary between Bancroft and
Elzevir terranes, the Bancroft shear zone, is a late tectonic extensional shear zone, marked by the presence of marble mylonites, with an inferred vertical offset of 5-6 km (van der Pluijm and Carlson 1989; Carlson et al. 1990).

\section{Elzevir terrane}

From its western margin with the Bancroft terrane toward its center, the Elzevir terrane is characterized by a variety of metaintrusive and metaextrusive rocks interlayered with marble (Davidson 1986). From the center toward its margin with the Sharbot Lake terrane, the Elzevir terrane contains a variety of plutonic rocks overlain by slope and shelf facies carbonates that are associated with bimodal volcanic and volcanoclastic rocks, which are in turn overlain by continental clastic sediments and shallow marine carbonates, metamorphosed from upper greenschist to amphibolite facies conditions (Davidson 1986; Rivers et al. 1989). Davis and Bartlett (1988) report chronological evidence for thrusting within the central Elzevir terrane at $\sim 1250 \mathrm{Ma}$, predating the peak of regional metamorphism in the CMB which they conclude to be between 1102 and $1088 \mathrm{Ma}$, The available $\mathrm{Rb} / \mathrm{Sr}$ whole rock ages and discordant $\mathrm{U} / \mathrm{Pb}$ zircon and sphene ages from pretectonic intrusive rocks of this area suggest emplacement ages of $\sim 1250 \mathrm{Ma}$ with metamorphic ages of $\sim 1085 \mathrm{Ma}$ (Silver and Lumbers 1966; Bell and Blenkinsop 1980; Heaman et al. 1986; Davis and Bartlett 1988; Corriveau 1990; Mezger et al. 1990). The variable metamorphic grades in the Elzevir terrane have been interpreted as evidence for two or even three periods of discrete metamorphic events in the CMB (Moore and Thompson 1980; Hanes et al. 1988).

\section{Sharbot Lake terrane}

The Sharbot Lake terrane (Easton 1989), is located between the Elzevir and Frontenac terranes (Fig. 1) and contains sedimentary and volcanic rocks metamorphosed to the amphibolite facies. The boundary between the Sharbot Lake terrane and the Elzevir terrane is marked by the presence of a narrow mylonite zone (the Robertson Lake Mylonite Zone), which dips approximately $30^{\circ}$ to the southeast affecting marbles and mafic schists (Easton 1988). This boundary separates rocks of amphibolite facies in the Sharbot Lake terrane from upper greenschist facies rocks in the Elzevir terrane. Farther to the southeast, the Sharbot Lake terrane is separated from the Frontenac terrane by a boundary (the Sharbot Lake mylonite zone) which is approximately $250-300 \mathrm{~m}$ wide and is marked by the presence of mylonites dipping $60-70^{\circ}$ to the southeast (Easton 1988). There are changes in lithologies and an abrupt change in metamorphic facies across this boundary from amphibolite facies in the Sharbot Lake terrane to granulite facies in the Frontenac terrane. In addition, some small, mildly deformed granitic units cut across this boundary suggesting syn- to post-tectonic emplacement (Easton 1988). There is no clear consensus at present regarding the precise location of this terrane boundary. Some suggestions as to where to place the boundary between the Frontenac and Sharbot Lake or Elzevir terranes include the Robertson Lake mylonite zone, the Rideau Lake fault, or the Perth road mylonite zone (eg. Davidson 1986; Corriveau 1990). For the purposes of this study, knowing which faults form the precise location of the terrane boundaries is of secondary importance to recognizing that these faults exist and determining to what extent, if any, they have affected the ${ }^{40} \mathrm{Ar} /{ }^{39} \mathrm{Ar}$ age data. As will be demonstrated, the use of ${ }^{40} \mathrm{Ar} /{ }^{39} \mathrm{Ar}$ age data is in fact a potentially useful tool in delineating the precise location of terrane boundaries in the CMB and elsewhere.

\section{Frontenac terrane}

The Frontenac terrane (Fig. 1) contains marbles in association with metapelites, quartzites, amphibolites, and orthogneisses, all metamorphosed from upper amphibolite to granulite facies (Carmichael 
et al. 1978; Lonker 1980; Davidson 1986; Anovitz and Essene 1990). Zircons from less deformed granitic rocks that intrude marble and gneissic rocks in the Frontenac terrane have been dated by $\mathrm{U} / \mathrm{Pb}$ methods south and north of the Rideau Lake Fault to be between 1162-1176 Ma and 1090-1076 Ma, respectively (van Breemen and Davidson 1988; Marcantonio et al. 1990). Mylonite zones developed within the Frontenac terrane and along the boundary between the Frontenac and the Sharbot Lake terranes are clearly zones of localized shearing. The dominant regional structural fabrics are consistent with northwest directed shearing. Some superimposed structural indicators suggesting southeast directed shearing were identified (JM Moore pers. comm. 1989), although much of the mylonite zone contains few or no kinematic indicators (Easton pers. comm. 1990).

\section{Analytical methods}

Ten hornblendes, eight phlogopites and one muscovite were separated from samples of gneiss, amphibolite and marble. Mineral separates ( $>99 \%$ purity) for the ${ }^{40} \mathrm{Ar} /{ }^{39} \mathrm{Ar}$ analyses were obtained in the $100-120$ mesh $(0.15-0.125 \mathrm{~mm})$ size range using standard separation techniques.

\section{Electron microprobe analyses}

Quantitative electron microprobe analyses were performed on all 19 purified hornblendes and micas in polished grain mounts. Wavelength dispersive analyses were obtained using the Cameca CAMEBAX electron microprobe at the University of Michigan. Standard operating conditions consisted of a focused electron beam and sample currents of $10 \mathrm{nA}$ with an accelerating potential of $15 \mathrm{kV}$ for the hornblendes and $12 \mathrm{kV}$ for the micas using well-characterized natural and synthetic standards. Counting times were fixed at $30 \mathrm{~s}$ for major elements and $60 \mathrm{~s}$ for fluorine. All raw data were corrected for atomic number, absorption, and fluorescence using Cameca (PAP) software.

Representative analytical results are presented in Tables 1 and 2 . Some compositional variation was found among different mineral grains, especially among the phlogopites. Formulae (not shown) were calculated on the basis of the sum of the tetrahedral and octahedral cations (less $\mathrm{Ca}, \mathrm{Na}$ and $\mathrm{K}$ ) equal to 13 for hornblendes, 14 for phlogopites, and 12 for muscovite; the $\mathrm{Fe}^{2+} / \mathrm{Fe}^{3+}$ and $\mathrm{H}_{2} \mathrm{O}$ contents were calculated from the normalized formulae using charge balance considerations. With one exception (sample MC88-5), the hornblendes vary little in composition and are similar to hornblendes previously analyzed from the Grenville Orogen (Cosca et al.

Table 1. Average electron microprobe analyses of hornblendes analyzed for ${ }^{40} \mathrm{Ar} /{ }^{39} \mathrm{Ar}$. Numbers in parentheses are standard deviations. ${ }^{a}$ Calculated from normalized formula

\begin{tabular}{|c|c|c|c|c|c|c|c|c|c|}
\hline & FA86-11 & FA86-4 & FA86-5 & FA86-6 & HL86-1 & MC87-22B & MC88-2 & MC88-5 & MC88-7 \\
\hline $\mathrm{SiO}_{2}$ & $44.27(0.63)$ & $41.87(0.37)$ & $41.86(0.31)$ & $41.18(0.54)$ & $45.04(0.50)$ & $44.21(C$ & $42.65(0.98)$ & $42.90(1.98)$ & $40.28(0.23)$ \\
\hline $\mathrm{TiO}_{2}$ & $1.02(0.02)$ & $2.23(0.30)$ & $2.44(0.11)$ & $2.52(0.33)$ & $0.61(0.06)$ & $1.15(0.07)$ & $1.43(0.40)$ & $0.48(0.20)$ & $0.79(0.10)$ \\
\hline $\mathrm{Al}_{2} \mathrm{O}_{3}$ & $10.63(0.14)$ & $10.89(0.14)$ & $11.48(0.21)$ & $11.55(0.12)$ & $12.14(0.40)$ & $7.29(0.11)$ & $10.23(0.42)$ & $12.57(2.37)$ & $12.50(0.15)$ \\
\hline $\mathrm{Fe}_{2} \mathrm{O}_{3}{ }^{\mathrm{a}}$ & $4.97(0.47)$ & $1.86(0.52)$ & $2.73(0.70)$ & $1.45(0.85)$ & $5.83(0.67)$ & $4.80(0.63)$ & $4.03(0.99)$ & $6.45(0.92)$ & $6.38(0.24)$ \\
\hline $\mathrm{FeO}^{*}$ & $11.36(0.44)$ & $12.67(0.61)$ & $11.75(0.80)$ & $16.33(0.55)$ & $8.04(0.82)$ & $18.52(0.73)$ & $11.69(1.11)$ & $9.04(3.46)$ & $19.92(0.14)$ \\
\hline $\mathrm{MnO}$ & $0.28(0.04)$ & $0.20(0.02)$ & $0.29(0.04)$ & $0.12(0.03)$ & $0.35(0.04)$ & $0.51(0.04)$ & $0.42(0.03)$ & $0.28(0.03)$ & $0.41(0.03)$ \\
\hline $\mathrm{MgO}$ & $11.21(0.19)$ & $11.53(0.34)$ & $11.53(0.31)$ & $9.1(0.06)$ & $12.36(0.23)$ & $7.72(0.11)$ & $11.93(0.56)$ & $11.64(1.73)$ & $4.54(0.04)$ \\
\hline $\mathrm{CaO}$ & $11.61(0.19)$ & $11.79(0.17)$ & $11.65(0.12)$ & $11.43(0.08)$ & $11.85(0.23)$ & $10.83(0.18)$ & $11.47(0.24)$ & $11.56(0.25)$ & $10.90(0.09)$ \\
\hline $\mathrm{Na}_{2} \mathrm{O}$ & $1.40(0.03)$ & $1.51(0.11)$ & $1.48(0.08)$ & $1.60(0.17)$ & $1.30(0.05)$ & $1.71(0.07)$ & $2.06(0.11)$ & $1.82(0.34)$ & $1.81(0.03)$ \\
\hline $\mathrm{K}_{2} \mathrm{O}$ & $0.83(0.02)$ & $1.87(0.07)$ & $1.82(0.07)$ & $1.94(0.05)$ & $0.25(0.02)$ & $1.15(0.02)$ & $1.82(0.04)$ & $0.80(0.51)$ & $1.07(0.09)$ \\
\hline $\mathrm{H}_{2} \mathrm{O}^{\mathrm{a}}$ & $1.88(0.07)$ & $1.50(0.15)$ & $1.44(0.08)$ & $1.47(0.09)$ & $2.02(0.04)$ & $1.53(0.10)$ & $0.94(0.14)$ & $1.86(0.09)$ & $1.72(0.01)$ \\
\hline $\mathrm{F}_{2}$ & $0.28(0.13)$ & $0.53(0.32)$ & $0.88(0.16)$ & $0.75(0.26)$ & $0.09(0.07)$ & $0.77(0.22)$ & $2.06(0.27)$ & $0.18(0.08)$ & $0.32(0.02)$ \\
\hline $\mathrm{Cl}_{2}$ & $0.04(0.01)$ & $0.89(0.08)$ & $0.54(0.04)$ & $0.53(0.12)$ & $0.05(0.01)$ & $0.25(0.03)$ & $0.32(0.03)$ & $0.36(0.20)$ & $0.29(0.02)$ \\
\hline $\mathrm{O}=\mathrm{F}_{2}$ & $0.12(0.06)$ & $0.22(0.14)$ & $0.37(0.07)$ & $0.31(0.11)$ & $0.03(0.03)$ & $0.33(0.09)$ & $0.87(0.11)$ & $0.07(0.03)$ & $0.14(0.01)$ \\
\hline $\mathrm{O}=\mathrm{Cl}_{2}$ & $0.01(0.01)$ & $0.20(0.02)$ & $0.12(0.01)$ & $0.12(0.03)$ & $0.01(0.01)$ & $0.06(0.01)$ & $0.07(0.01)$ & $0.08(0.05)$ & $0.07(0.01)$ \\
\hline Sum & 99.65 & 98.92 & 99.40 & 99.54 & 99.89 & 100.04 & 100.11 & 99.79 & 100.72 \\
\hline
\end{tabular}

Table 2. Average electron microprobe analyses of phlogopites and muscovite (GO-12) analyzed by ${ }^{40} \mathrm{Ar} /{ }^{39} \mathrm{Ar}$. Numbers in parentheses are standard deviations. ${ }^{2}$ Calculated from normalized formula

\begin{tabular}{|c|c|c|c|c|c|c|c|c|c|}
\hline & BA-O & BA-11 & BA-31A & $\mathrm{MC} 87-22 \mathrm{~A}$ & MC88-8 & $\mathrm{GO}-1 \mathrm{~B}$ & WI-1A & WI-1B & GO-12 \\
\hline $\mathrm{SiO}_{2}$ & $43.00(1.94)$ & $39.61(0.58)$ & $40.87(0.16)$ & $40.10(0.02)$ & $40.98(0.15)$ & $40.73(0.24)$ & $44.55(0.02)$ & $43.31(1.19)$ & $45.18(0.73)$ \\
\hline $\mathrm{TiO}_{2}$ & $0.75(0.18)$ & $1.10(0.10)$ & $0.26(0.03)$ & $0.31(0.01)$ & $0.14(0.05)$ & $0.46(0.05)$ & $0.25(0.03)$ & $0.21(0.02)$ & $0.92(0.21)$ \\
\hline $\mathrm{Al}_{2} \mathrm{O}_{3}$ & $8.33(0.40)$ & $14.52(0.14)$ & $12.13(0.22)$ & $12.66(0.57)$ & $12.13(0.72)$ & $12.58(0.15)$ & $9.57(0.10)$ & $10.69(1.22)$ & $35.92(0.06)$ \\
\hline $\mathrm{Cr}_{2} \mathrm{O}_{3}$ & $0.06(0.04)$ & $0.05(0.04)$ & $0.03(0.01)$ & $0.11(0.01)$ & $0.06(0.06)$ & $0.08(0.02)$ & $0.08(0.01)$ & $0.05(0.03)$ & $0.05(0.03)$ \\
\hline $\mathrm{Fe}_{2} \mathrm{O}_{3}^{\mathrm{a}}$ & 0 & $2.17(0.54)$ & $3.18(0.47)$ & $0.32(0.14)$ & $1.09(0.06)$ & $0.61(0.01)$ & 0 & $0.67(0.60)$ & $1.02(0.12)$ \\
\hline $\mathrm{FeO}^{*}$ & $5.74(1.34)$ & $0.70(0.34)$ & $0.46(0.54)$ & 0 & 0 & 0 & $2.31(0.03)$ & $0.24(0.22)$ & 0 \\
\hline $\mathrm{MgO}$ & $21.98(1.05)$ & $26.09(0.49)$ & $26.71(0.26)$ & $28.29(0.08)$ & $29.00(0.18)$ & $28.76(0.07)$ & $26.46(0.02)$ & $28.16(0.61)$ & $0.63(0.09)$ \\
\hline $\mathrm{BaO}$ & $0.13(0.02)$ & $0.11(0.03)$ & $0.22(0.12)$ & $0.76(0.31)$ & $0.36(0.02)$ & $1.70(0.18)$ & $0.10(0.06)$ & $0.33(0.25)$ & $0.46(0.09)$ \\
\hline $\mathrm{Na}_{2} \mathrm{O}$ & $0.26(0.08)$ & $0.07(0.03)$ & $0.42(0.01)$ & $0.31(0.02)$ & $1.50(0.02)$ & $1.20(0.10)$ & $0.39(0.01)$ & $1.02(0.55)$ & $1.24(0.09)$ \\
\hline $\mathrm{K}_{2} \mathrm{O}$ & $9.23(0.71)$ & $10.12(0.22)$ & $9.51(0.14)$ & $9.96(0.16)$ & $7.54(0.06)$ & $8.20(0.17)$ & $10.19(0.05)$ & $8.99(0.66)$ & $8.12(0.04)$ \\
\hline $\mathrm{H}_{2} \mathrm{O}^{\mathrm{a}}$ & $0.18(0.01)$ & $3.71(0.08)$ & $1.06(0.10)$ & $1.22(0.08)$ & $1.21(0.02)$ & $1.04(0.11)$ & $0.16(0.03)$ & $0.53(0.28)$ & $4.59(0.01)$ \\
\hline $\mathrm{F}_{2}$ & $7.78(0.18)$ & $0.94(0.15)$ & $6.57(0.22)$ & $6.25(0.13)$ & $6.42(0.02)$ & $6.73(0.25)$ & $8.46(0.13)$ & $7.77(0.50)$ & $0.05(0.01)$ \\
\hline $\mathrm{Cl}_{2}$ & $0.05(0.02)$ & $0.35(0.04)$ & $0.04(0.01)$ & $0.03(0.01)$ & $0.03(0.01)$ & $0.03(0.01)$ & $0.03(0.01)$ & $0.03(0.02)$ & $0.03(0.02)$ \\
\hline $\mathrm{O}=\mathrm{F}_{2}$ & $3.28(0.08)$ & $0.40(0.06)$ & $2.77(0.09)$ & $2.64(0.05)$ & $2.70(0.02)$ & $2.83(0.10)$ & $3.57(0.05)$ & $3.27(0.21)$ & $0.01(0.01)$ \\
\hline $\mathrm{O}=\mathrm{Cl}_{2}$ & $0.01(0.01)$ & $0.08(0.01)$ & $0.01(0.01)$ & $0.01(0.01)$ & $0.01(0.01)$ & $0.01(0.01)$ & $0.01(0.01)$ & $0.01(0.01)$ & $0.01(0.01)$ \\
\hline Sum & 94.20 & 99.06 & 98.68 & 97.67 & 97.75 & 99.28 & 98.97 & 98.72 & 98.19 \\
\hline
\end{tabular}


1991b). The phlogopites have extreme variations in fluorine content and in some samples fluorine almost exclusively occupies the $\mathrm{OH}$ site (e.g. BA-O, WI-1A); their sodium and barium contents vary from 0 to $20 \%$ of the $\mathrm{K}$ site. The analytical totals of some phlogopites (Table 2) and problematic (e.g. sample BA-O) and should be viewed with caution. Although the phlogopites were prepared in casted resin mounts and polished using an automated diamond polishing wheel, not every grain yielded an adequate polish. This is suspected as the primary reason for the low analytical totals. However, small amounts of a clay mineral with a basal spacing of 19 angstroms was detected by powder X-ray diffraction in sample BA-O and may have contributed to the low analytical totals in this sample.

${ }^{40} \mathrm{Ar} /{ }^{39} \mathrm{Ar}$ procedures

Argon isotopic measurements were made at the United States Geological Survey in Reston, Va. Samples and mineral standards were weighed into tin capsules, numbered, and sealed in evacuated quartz vials. The vials containing samples interspersed with standards were irradiated in the central thimble position of the United States Geological Survey TRIGA reactor at the Federal Center in Fenver, Colo, for a total of $60 \mathrm{MW} \mathrm{h}$.

All gas extractions were accomplished with a double vacuum resistance furnace containing a molybdenum-lined tantalum crucible. Samples were progressively degassed in steps, the temperature of which was determined $\left( \pm 5^{\circ} \mathrm{C}\right)$ using a $5 \% \mathrm{~W} / \mathrm{Re}-26 \% \mathrm{~W} / \mathrm{Re}$ thermocouple inserted in the base of the tantalum crucible. Gases were purified by exposure to hot $\mathrm{Ti}$ and $\mathrm{Zr} / \mathrm{Al}$ getters, and then equilibrated and analyzed statically with a VG MICROMASS $1200 \mathrm{~B}$ mass spectrometer.

Raw isotopic abundances were determined by time zero linear regression of peak heights above baselines during five sequential scans through mass numbers 40 to 35 . These data were corrected for mass discrimination, interfering $\mathrm{Ca}, \mathrm{K}$, and $\mathrm{Cl}$ derived isotopes of argon, and decay subsequent to the time of irradiation. Ages were calculated with the algorithm of Haugerud and Kunk (1988) using the production ratios for interfering isotopes given in Dalrymple et al. (1981) and the decay constants recommended by Steiger and Jäger (1977). Correlation of ${ }^{40} \mathrm{Ar},{ }^{39} \mathrm{Ar}$, and ${ }^{36} \mathrm{Ar}$ isotopes indicates that no detectable trapped argon different in composition from atmospheric ${ }^{40} \mathrm{Ar} /{ }^{36} \mathrm{Ar}$ was present; therefore, a trapped or "initial" value of ${ }^{40} \mathrm{Ar} /{ }^{36} \mathrm{Ar}=295.5$ was assumed for all calculations. Although ${ }^{38} \mathrm{Ar}$ and ${ }^{37} \mathrm{Ar}$ were measured for all samples, ${ }^{37} \mathrm{Ar}$ is only reported for hornblendes due to the extremely small concentrations of these isotopes in the phlogopites. System blanks were measured periodically throughout the duration of the analyses yielding typical ${ }^{40} \mathrm{Ar}$ blanks, at temperatures of $700^{\circ} \mathrm{C}$ and $1500^{\circ} \mathrm{C}$, of 4.6 to 7.6 $\times 10^{-15} \mathrm{~mol}$ respectively. Mass discrimination factors were determined by analysis of atmospheric argon prior to analyses. Neutron flux gradients were monitored with the $520.4 \mathrm{Ma}$ hornblende standard MMhb-1 (Samson and Alexander 1987) positioned along the length of the sample package. Gradients in neutron flux (J) were determined with a precision of $0.25 \%$.

\section{Closure temperatures}

Closure temperatures used for this investigation are based on published experimental data or geologically constrained estimates for conditions of slow cooling $\left(<5^{\circ} \mathrm{C} / \mathrm{Ma}\right.$ ). For hornblende a value of $\sim 480^{\circ} \mathrm{C}$ is assumed (Harrison 1981; Baldwin et al. 1990). The experiments by Giletti (1974) and Harrison et al. (1985) indicate that argon closure temperatures increase by $200^{\circ} \mathrm{C}$ from annite to phlogopite. The experimental data of Giletti (1974) combined with diffusional parameters of Harrison et al. (1985) yield a closure temperature of $500^{\circ} \mathrm{C}$ for phlogopite. At present it is difficult to evaluate whether such a high closure temperature for phlogopite is geologically reasonable. The $200^{\circ} \mathrm{C}$ variation in apparent closure temperature with variable $\mathrm{Mg} /\left(\mathrm{Mg}+\mathrm{Fe}^{2+}\right)$ ratios is so large that additional well-controlled experiments appear necessary to refine these values. Although variation in $\mathrm{Mg} /\left(\mathrm{Mg}+\mathrm{Fe}^{2+}\right)$ among phlogopites of this study is small (0.85-1), extreme variation of $0.1-1$ in $\mathrm{OH} /(\mathrm{F}+\mathrm{OH})$ is observed, and it is kot known what effect this substitution might have on argon retentivity in phlogopite.

\section{Analytical results}

\section{Hornblende}

Analytical results for hornblendes are listed in Table 3 and their ${ }^{40} \mathrm{Ar} /{ }^{39} \mathrm{Ar}$ age spectra are shown in Fig. 2 . Most of the hornblendes in this study were collected from the Elzevir, Sharbot Lake, and the Frontenac terranes (Fig. 2). The ${ }^{40} \mathrm{Ar} /{ }^{39} \mathrm{Ar}$ spectra are generally flat and similar to those of nearby samples collected for an earlier study (Cosca et al. 1991a). Age plateaus were determined for samples that released $>50 \%$ of the ${ }^{39} \mathrm{Ar}$ in two or more consecutive steps each having ${ }^{40} \mathrm{Ar} /{ }^{39} \mathrm{Ar}$ ratios indistinguishable at the $95 \%$ confidence level. Following these criteria, most spectra define age plateaus. The hornblende ${ }^{40} \mathrm{Ar} /{ }^{39} \mathrm{Ar}$ plateau ages range from $1125 \pm 3 \mathrm{Ma}$ in the Frontenac terrane to $934 \pm 3 \mathrm{Ma}$ in the Elzevir terrane. The difference of nearly $200 \mathrm{Ma}$ in hornblende ${ }^{40} \mathrm{Ar} /{ }^{39} \mathrm{Ar}$ cooling ages between these terranes confirms the pattern recognized earlier (Cosca et al. 1991a) in which hornblende plateau ages were found to range from $1104 \mathrm{Ma}$ in the Frontenac terrane to $919 \pm 3 \mathrm{Ma}$ in the Elzevir terrane. Unlike the $\sim 100 \mathrm{Ma}$ range in $\mathrm{U} / \mathrm{Pb}$ zircon ages north and south of the Rideau Lake Fault within the Frontenac terrane (Marcantonio et al. 1990), no variation in hornblende ${ }^{40} \mathrm{Ar} /{ }^{39} \mathrm{Ar}$ cooling ages is observed. Moreover, no variation in hornblende ${ }^{40} \mathrm{Ar} /{ }^{39} \mathrm{Ar}$ cooling ages is found across the Perth Road Mylonite Zone, also within the Frontenac terrane (Fig. 2).

Hornblende ${ }^{40} \mathrm{Ar} /{ }^{39} \mathrm{Ar}$ cooling ages from the $\mathrm{CMB}$ analyzed during this study together with results from Cosca et al. (1991a) are illustrated in Fig. 3. While only limited variations in hornblende ${ }^{40} \mathrm{Ar} /{ }^{39} \mathrm{Ar}$ cooling ages occur within each of the terranes, these data show clear and dramatic variations in hornblende ${ }^{40} \mathrm{Ar} /{ }^{39} \mathrm{Ar}$ age between the different terranes of the CMB. The most significant variations in age occur over small distances between the Sharbot Lake and Elzevir terranes, and between the Frontenac and Sharbot Lake terranes.

When hornblende compositions are evaluated with respect to ${ }^{40} \mathrm{Ar} /{ }^{39} \mathrm{Ar}$ age, no systematic correlation is evident. Figure 4 contains hornblende compositional data for samples of this study together with hornblende data from an earlier study (Cosca et al. 1991b). In general, these samples are magnesian hastingsitic hornblendes, ferroan pargasitic hornblendes, and magnesio hornblendes. A significant range in A-site occupancy is observed in these samples, but as seen in Fig. 4 both young and old hornblendes have similar variations, suggesting that composition is not a significant variable in the dramatic ${ }^{40} \mathrm{Ar} /{ }^{39} \mathrm{Ar}$ age variations of these samples.

\section{Phlogopite}

Phlogopites (and one muscovite) were sampled from marbles and marble mylonites in close proximity to the NESW striking extensional mylonite zone ("Bancroft Shear 
Table 3. ${ }^{40} \mathrm{Ar} /{ }^{39} \mathrm{Ar}$ data collected from hornblendes. 1 sigma errors on ages calculated for intra-package reproducibility

\begin{tabular}{|c|c|c|c|c|c|c|c|c|}
\hline $\mathrm{T}\left({ }^{\circ} \mathrm{C}\right)$ & ${ }^{40} \mathrm{Ar} /{ }^{39} \mathrm{Ar}$ & ${ }^{37} \mathrm{Ar} /{ }^{39} \mathrm{Ar}$ & $\begin{array}{l}{ }^{36} \mathrm{Ar} /{ }^{39} \mathrm{Ar} \\
\left(\times 10^{-2}\right)\end{array}$ & $\begin{array}{l}{ }^{39} \mathrm{Ar}_{\mathrm{K}} \\
\text { (\% of } \\
\text { total) }\end{array}$ & $\begin{array}{l}{ }^{40} \mathrm{Ar}_{\mathrm{R}} \\
(\% \text { of } \\
\text { total })\end{array}$ & $\begin{array}{l}{ }^{39} \mathrm{Ar}_{\mathbf{K}} \\
\left(\times 10^{-12}\right. \\
\text { moles })\end{array}$ & $\begin{array}{l}\text { Apparent } \\
\mathrm{K} / \mathrm{Ca} \\
(\mathrm{mol} / \mathrm{mol})\end{array}$ & $\begin{array}{l}\text { Apparent } \\
\text { Age (Ma) }\end{array}$ \\
\hline \multicolumn{9}{|c|}{ FA86-1 Hornblende; $\mathrm{J}=0.014384 ; \mathrm{wt}=0.2198 \mathrm{~g}$} \\
\hline 1050 & 58.35 & 4.23 & 0.37 & 24.2 & 98.2 & 2.02 & 0.12 & $1099 \pm 3$ \\
\hline 1100 & 60.02 & 4.52 & 0.07 & 38.3 & 99.7 & 3.20 & 0.11 & $1123 \pm 3$ \\
\hline 1125 & 59.43 & 4.57 & 0.15 & 10.7 & 99.2 & 0.90 & 0.11 & $1115 \pm 2$ \\
\hline 1150 & 59.23 & 4.60 & 0.38 & 8.3 & 98.1 & 0.70 & 0.11 & $1112 \pm 3$ \\
\hline 1175 & 59.94 & 4.58 & 0.22 & 11.0 & 98.9 & 0.92 & 0.11 & $1122 \pm 3$ \\
\hline 1200 & 58.98 & 4.50 & $<0.01$ & 2.9 & 98.8 & 0.24 & 0.12 & $1108 \pm 9$ \\
\hline Fuse & 58.69 & 4.52 & 0.41 & 4.5 & 98.0 & 0.38 & 0.12 & $1104 \pm 6$ \\
\hline
\end{tabular}

Total-gas age $=1114 \mathrm{Ma}$
Plateau age $\left(1100-1175^{\circ} \mathrm{C}\right)=1117 \pm 3 \mathrm{Ma}$

FA86-4 Hornblende; $\mathbf{J}=0.014384 ; \mathrm{wt}=0.2112 \mathrm{~g}$

\begin{tabular}{|c|c|c|c|c|c|c|c|c|}
\hline 850 & 48.22 & 2.28 & 3.69 & 3.0 & 81.6 & 0.33 & 0.23 & $950 \pm 4$ \\
\hline 1125 & 56.08 & 2.66 & 0.27 & 5.2 & 98.6 & 0.58 & 0.20 & $1067 \pm 4$ \\
\hline 1175 & 58.97 & 2.90 & 0.18 & 8.3 & 99.1 & 0.92 & 0.18 & $1108 \pm 3$ \\
\hline 1200 & 59.38 & 2.90 & 0.18 & 57.8 & 99.1 & 6.43 & 0.18 & $1114 \pm 4$ \\
\hline 1225 & 60.20 & 3.03 & 0.09 & 12.0 & 99.5 & 1.34 & 0.17 & $1125 \pm 2$ \\
\hline 1250 & 60.55 & 3.55 & $<0.01$ & 9.2 & 99.7 & 1.02 & 0.15 & $1130 \pm 3$ \\
\hline Fuse & 60.75 & 4.96 & 0.28 & 4.5 & 98.7 & 0.50 & 0.10 & $1133 \pm 4$ \\
\hline \multicolumn{9}{|c|}{ Total-gas age $=1110 \mathrm{Ma}$} \\
\hline \multicolumn{9}{|c|}{ Plateau age $\left(1175-1200^{\circ} \mathrm{C}\right)=1109 \pm 3 \mathrm{Ma}$} \\
\hline \multicolumn{9}{|c|}{ FA86-5 Hornblende; $\mathrm{J}=0.014384 ; \mathrm{wt}=0.2256 \mathrm{~g}$} \\
\hline 1050 & 58.85 & 2.92 & 0.47 & 7.1 & 97.7 & 0.79 & 0.18 & $1106 \pm 3$ \\
\hline 1100 & 57.89 & 2.85 & 0.02 & 43.1 & 98.9 & 4.78 & 0.18 & $1093 \pm 3$ \\
\hline 1125 & 59.06 & 3.00 & $<0.01$ & 16.8 & 99.7 & 1.87 & 0.17 & $1109 \pm 3$ \\
\hline 1150 & 60.28 & 3.20 & 0.13 & 11.8 & 99.4 & 1.31 & 0.16 & $1126 \pm 2$ \\
\hline 1175 & 60.41 & 3.35 & $<0.01$ & 14.2 & 99.9 & 1.58 & 0.16 & $1128 \pm 3$ \\
\hline Fuse & 60.60 & 3.42 & 0.14 & 6.9 & 99.3 & 0.77 & 0.15 & $1131 \pm 3$ \\
\hline
\end{tabular}

Total-gas age $=1108$

Preferred age $=1093 \mathrm{Ma}$

FA86-6 Hornblende; $\mathbf{J}=0.014482 ; \mathrm{wt}=0.2061 \mathrm{~g}$

\begin{tabular}{|c|c|c|c|c|c|c|c|c|}
\hline 1000 & 47.08 & 6.87 & 2.67 & 1.7 & 85.7 & 0.23 & 0.08 & $938 \pm 5$ \\
\hline 1050 & 59.33 & 2.72 & $<0.01$ & 14.4 & 100.0 & 2.02 & 0.19 & $1119 \pm 3$ \\
\hline 1075 & 59.27 & 2.72 & 0.10 & 12.9 & 99.5 & 1.82 & 0.19 & $1118 \pm 3$ \\
\hline 1100 & 59.38 & 2.66 & $<0.01$ & 11.0 & 100.0 & 1.55 & 0.20 & $1119 \pm 4$ \\
\hline 1125 & 59.04 & 2.69 & $<0.01$ & 13.0 & 99.7 & 1.84 & 0.19 & $1115 \pm 2$ \\
\hline 1150 & 59.65 & 2.68 & $<0.01$ & 10.5 & 99.8 & 1.49 & 0.19 & $1123 \pm 3$ \\
\hline 1175 & 59.79 & 2.71 & $<0.01$ & 7.9 & 99.8 & 1.12 & 0.19 & $1125 \pm 2$ \\
\hline 1200 & 59.71 & 2.84 & $<0.01$ & 17.6 & 100.0 & 2.47 & 0.18 & $1124 \pm 2$ \\
\hline 1225 & 59.61 & 2.72 & 0.15 & 6.8 & 99.3 & 0.95 & 0.19 & $1123 \pm 2$ \\
\hline Fuse & 59.47 & 2.72 & 0.18 & 4.2 & 99.1 & 0.59 & 0.19 & $1121 \pm 2$ \\
\hline
\end{tabular}

Total-gas age $=1118 \mathrm{Ma}$

Plateau age $\left(1050-1125^{\circ} \mathrm{C}\right)=1117 \pm 3 \mathrm{Ma}$

MC88-7 Hornblende; $\mathbf{J}=0.014482 ; \mathrm{wt}=0.2273 \mathrm{~g}$

\begin{tabular}{|c|c|c|c|c|c|c|c|c|}
\hline 1000 & 47.47 & 4.85 & 0.25 & 65.1 & 98.5 & 5.09 & 0.11 & $944 \pm 2$ \\
\hline 1050 & 47.06 & 4.83 & 0.10 & 10.0 & 99.4 & 0.78 & 0.11 & $937 \pm 3$ \\
\hline 1075 & 46.09 & 5.40 & 0.30 & 6.3 & 98.1 & 0.49 & 0.10 & $922 \pm 3$ \\
\hline 1125 & 46.79 & 5.84 & 0.13 & 11.3 & 99.2 & 0.88 & 0.09 & $933 \pm 2$ \\
\hline 1175 & 46.79 & 5.62 & 0.27 & 5.8 & 98.3 & 0.45 & 0.09 & $933 \pm 4$ \\
\hline Fuse & 45.66 & 5.63 & 0.84 & 1.4 & 94.9 & 0.11 & 0.09 & $916 \pm 11$ \\
\hline
\end{tabular}

Total-gas age $=940 \mathrm{Ma}$

Plateau age $\left(1000-1125^{\circ} \mathrm{C}\right)=936 \pm 3 \mathrm{Ma}$

FA86-11 Hornblende; $\mathrm{J}=0.014384 ; \mathrm{wt}=0.2269 \mathrm{~g}$

$\begin{array}{rrrrrrrrr}850 & 51.23 & 13.71 & 13.78 & 0.6 & 55.7 & 0.04 & 0.04 & 9.08 \\ 950 & 45.51 & 6.57 & 2.70 & 1.0 & 85.1 & 0.06 & 908 \pm 22 \\ 975 & 42.63 & 6.99 & 2.68 & 0.8 & 84.3 & 0.04 & 0.07 & 863 \pm 39 \\ 1000 & 44.27 & 8.56 & 1.48 & 1.3 & 91.0 & 0.08 & 0.06 & 889 \pm 20 \\ 1050 & 46.20 & 8.03 & 0.34 & 5.0 & 97.9 & 0.29 & 0.06 \\ 1075 & 46.90 & 7.05 & 0.15 & 22.7 & 99.1 & 1.34 & 0.07 & 919 \pm 7 \\ 1100 & 47.32 & 6.78 & <0.01 & 15.7 & 99.6 & 0.93 & 0.08 & 930 \pm 3 \\ 1125 & 46.83 & 6.89 & 0.26 & 5.4 & 98.4 & 0.32 & 0.08 & 937 \pm 3 \\ 1150 & 47.02 & 7.16 & <0.01 & 7.2 & 99.2 & 0.42 & 0.07 & 929 \pm 2\end{array}$


Table 3. (continued)

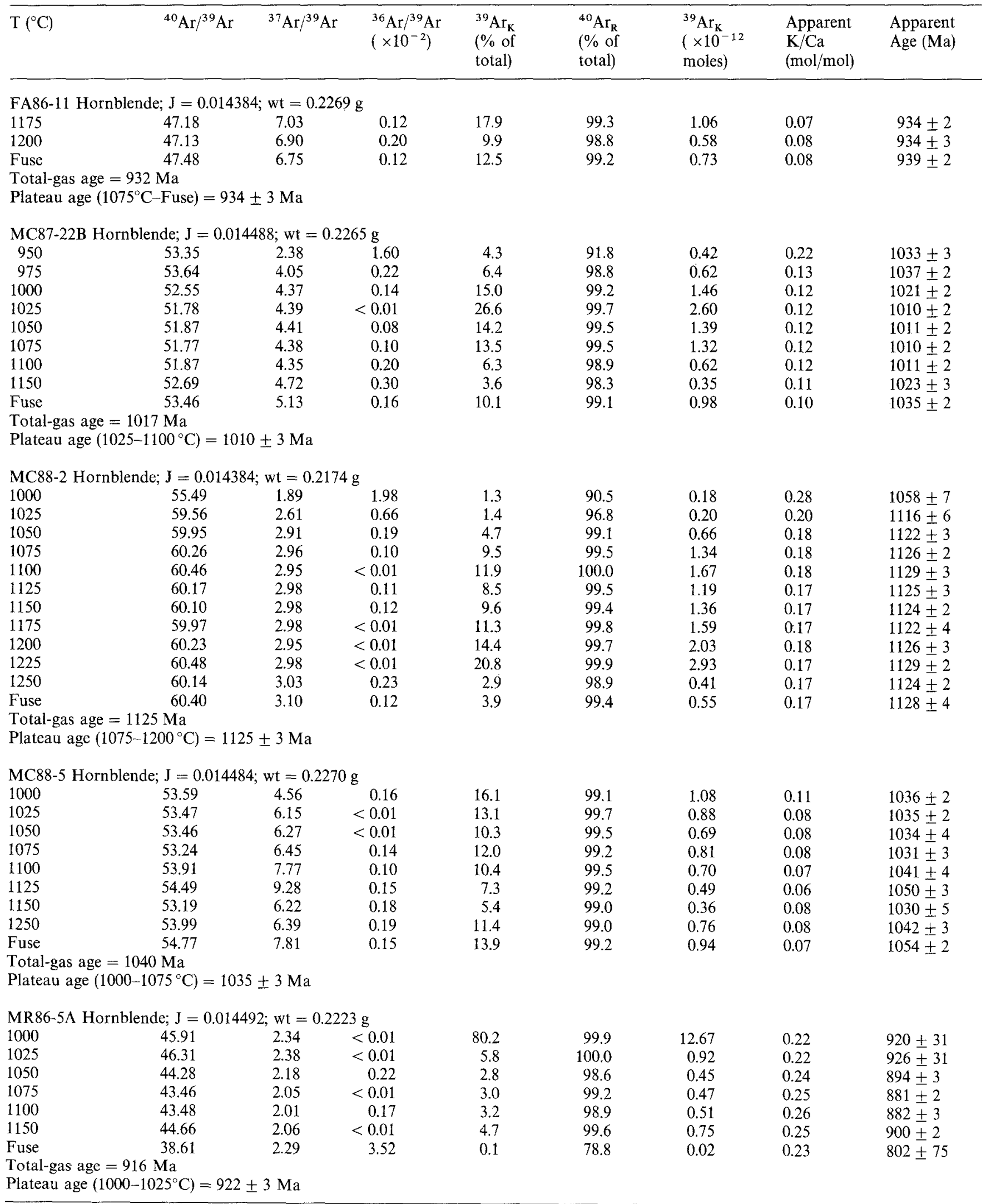

Zone"), which separates the Bancroft terrane from the Elzevir terrane (van der Pluijm and Carlson 1989). The ${ }^{40} \mathrm{Ar} /{ }^{39} \mathrm{Ar}$ data for the micas are given in Table 4 and are presented as age spectra in Fig. 5. Age plateaus were determined for the micas in the same manner as the hornblendes. Without exception, only phlogopites collected from unsheared marbles (protomylonites) yielded ${ }^{40} \mathrm{Ar} /{ }^{39} \mathrm{Ar}$ age plateaus, with plateau ages of $992 \pm 3 \mathrm{Ma}$ 


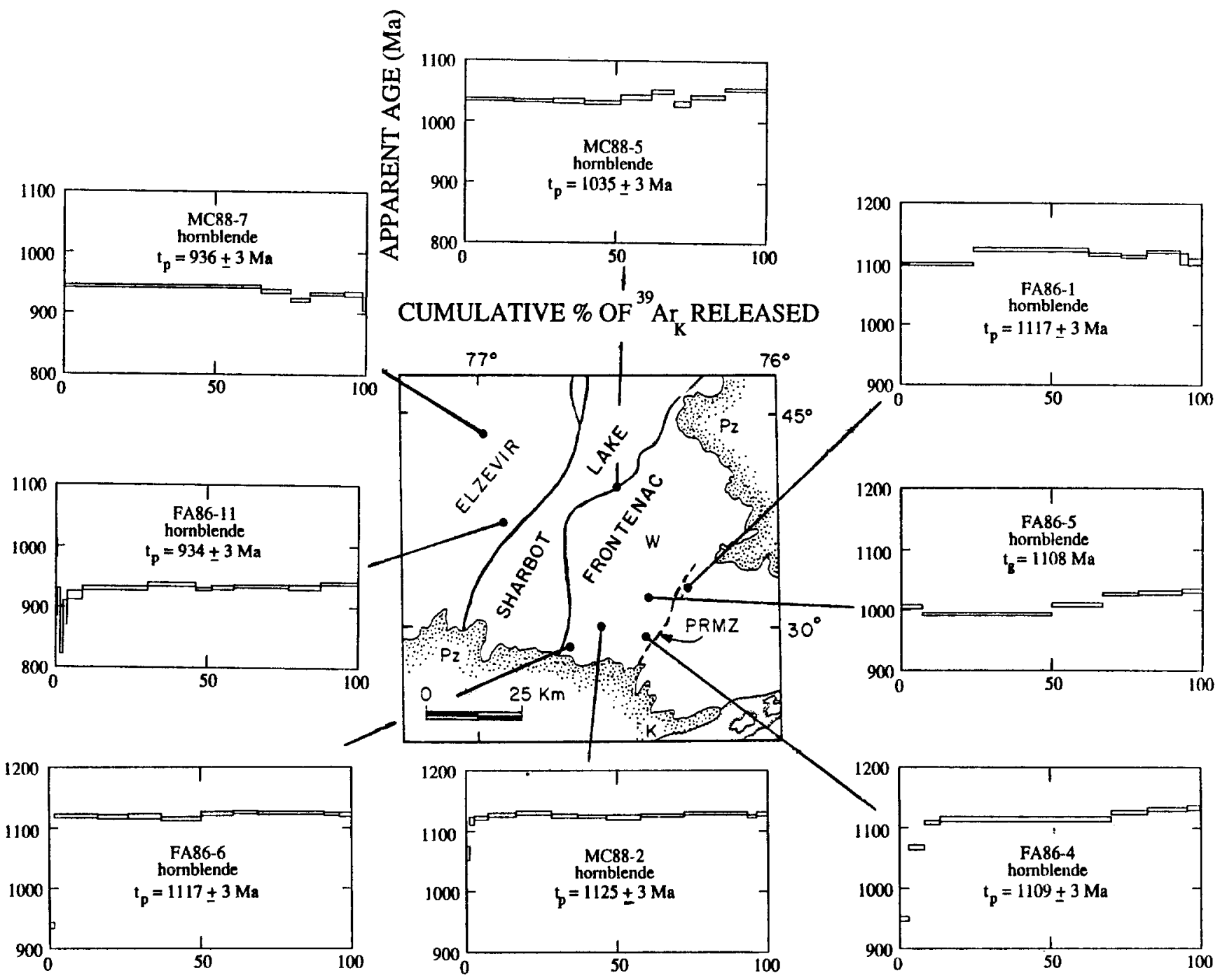

Fig. 2. ${ }^{40} \mathrm{Ar} /{ }^{39} \mathrm{Ar}$ release spectra of hornblendes from the Frontenac, Sharbot Lake, and Elzevir terranes within the CMB $\left(t_{p}\right.$, plateau age; $t_{g}$, total gas age). The terrane boundaries are taken from Easton (1988, 1989). PRMZ, Perth Road mylonite zone (location from Carmichael et al. 1987); $P z$, Paleozoic cover; $W$, Westport. The Robertson Lake shear zone separates the Elzevir and Sharbot Lake terranes; the Sharbot Lake mylonite zone separates the Sharbot Lake and Frontenac terranes

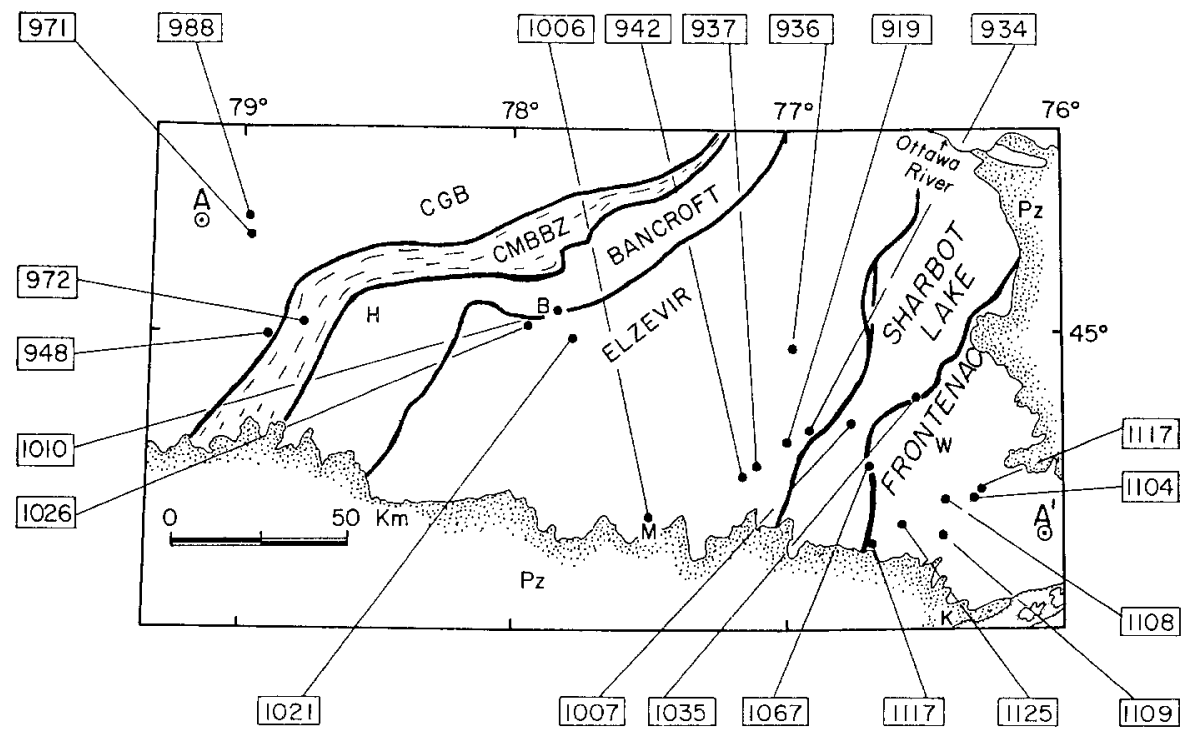

Fig. 3. Cumulative hornblende ${ }^{40} \mathrm{Ar} /{ }^{39} \mathrm{Ar}$ plateau ages (Ma) from the CMB, in Ontario. $H$, Haliburton; $B$, Bancroft; $M$, Madoc; $K$, Kingston; $P z$, Paleozoic cover. Also shown is the line of cross section $A-A^{\prime}$ 
southeast of the mylonite zone and $893 \pm 2$ and 904 $\pm 3 \mathrm{Ma}$ northwest of the mylonite zone. In contrast to the unsheared marbles, five phlogopites and one muscovite collected from sheared marbles within the Bancroft
Shear zone provided discordant age spectra (e.g. sample BA-31A), monotonically increasing in age with increasing laboratory temperature, yielding a range in ${ }^{40} \mathrm{Ar} /{ }^{39} \mathrm{Ar}$ total gas ages of 973 to $1117 \mathrm{Ma}$.

Table 4. ${ }^{40} \mathrm{Ar} /{ }^{39} \mathrm{Ar}$ data collected from phlogopites and muscovite. 1 sigma errors on ages calculated for intra-package reproducibility

\begin{tabular}{|c|c|c|c|c|c|c|}
\hline $\mathrm{T}\left({ }^{\circ} \mathrm{C}\right)$ & ${ }^{40} \mathrm{Ar} /{ }^{39} \mathrm{Ar}$ & $\begin{array}{l}{ }^{36} \mathrm{Ar} /{ }^{39} \mathrm{Ar} \\
\left(\times 10^{-2}\right)\end{array}$ & $\begin{array}{l}{ }^{39} \mathrm{Ar}_{\mathrm{K}} \\
(\% \text { of } \\
\text { total })\end{array}$ & $\begin{array}{l}{ }^{40} \mathrm{Ar}_{\mathrm{R}} \\
\text { (\% of } \\
\text { total) }\end{array}$ & $\begin{array}{l}{ }^{39} \mathrm{Ar}_{\mathrm{K}} \\
\left(\times 10^{-12}\right. \\
\text { moles })\end{array}$ & $\begin{array}{l}\text { Apparent } \\
\text { Age (Ma) }\end{array}$ \\
\hline \multicolumn{7}{|c|}{ BA-O Phlogopite; $\mathrm{J}=0.014528 ; \mathrm{wt}=0.0378 \mathrm{~g}$} \\
\hline 750 & 41.19 & 0.16 & 0.9 & 89.8 & 0.13 & $846 \pm 9$ \\
\hline 850 & 46.17 & 0.02 & 3.8 & 98.8 & 0.55 & $926 \pm 3$ \\
\hline 1050 & 47.79 & $<0.01$ & 32.3 & 99.7 & 4.71 & $951 \pm 4$ \\
\hline 1250 & 50.21 & $<0.01$ & 56.6 & 100.0 & 8.25 & $988 \pm 2$ \\
\hline Fuse & 50.91 & $<0.01$ & 6.3 & 100.0 & 0.92 & $999 \pm 3$ \\
\hline \multicolumn{7}{|c|}{ Total gas age $=973 \mathrm{Ma}$} \\
\hline \multicolumn{7}{|c|}{ BA-11 Phlogopite; $\mathrm{J}=0.014495 ; \mathrm{wt}=0.0388 \mathrm{~g}$} \\
\hline 850 & 48.92 & 0.16 & 0.5 & 91.2 & 0.08 & $967 \pm 17$ \\
\hline 1050 & 50.50 & $<0.01$ & 19.9 & 99.7 & 2.80 & $991 \pm 2$ \\
\hline 1150 & 50.58 & $<0.01$ & 26.9 & 99.8 & 3.79 & $992 \pm 2$ \\
\hline 1250 & 50.63 & $<0.01$ & 49.4 & 99.8 & 6.60 & $993 \pm 2$ \\
\hline Fuse & 50.91 & 0.02 & 3.2 & 99.0 & 0.45 & $997 \pm 2$ \\
\hline
\end{tabular}

Total gas age $=992 \mathrm{Ma}$

Plateau age $\left(850-1250^{\circ} \mathrm{C}\right)=992 \pm 3 \mathrm{Ma}$

\begin{tabular}{|c|c|c|c|c|c|c|}
\hline \multicolumn{7}{|c|}{ BA-31A Phlogopite; $\mathrm{J}=0.014444 ; \mathrm{wt}=0.0380 \mathrm{~g}$} \\
\hline 850 & 54.11 & 0.02 & 4.2 & 98.7 & 0.59 & $1042 \pm 2$ \\
\hline 950 & 56.35 & $<0.01$ & 11.5 & 99.8 & 1.60 & $1074 \pm 2$ \\
\hline 1050 & 57.47 & 0.01 & 24.5 & 99.6 & 3.43 & $1090 \pm 2$ \\
\hline 1100 & 59.54 & $<0.01$ & 14.2 & 100.0 & 1.99 & $1119 \pm 3$ \\
\hline 1150 & 60.57 & $<0.01$ & 15.5 & 100.0 & 2.17 & $1134 \pm 2$ \\
\hline 1200 & 61.51 & $<0.01$ & 14.8 & 99.9 & 2.07 & $1147 \pm 3$ \\
\hline 1250 & 62.36 & $<0.01$ & 9.6 & 100.0 & 1.34 & $1159 \pm 3$ \\
\hline Fuse & 63.05 & 0.02 & 5.7 & 99.3 & 0.80 & $1168 \pm 3$ \\
\hline \multicolumn{7}{|c|}{ Total gas age $=1117 \mathrm{Ma}$} \\
\hline \multicolumn{7}{|c|}{ GO-1B Phlogopite; $\mathrm{J}=0.014364$; wt $=0.0377 \mathrm{~g}$} \\
\hline 850 & 38.48 & 0.57 & 0.6 & 69.6 & 0.08 & $794 \pm 29$ \\
\hline 1050 & 45.00 & 0.01 & 11.8 & 99.5 & 1.41 & $899 \pm 2$ \\
\hline 1150 & 44.48 & $<0.01$ & 16.2 & 99.4 & 1.93 & $891 \pm 3$ \\
\hline 1250 & 44.55 & 0.01 & 40.2 & 99.6 & 4.80 & $892 \pm 2$ \\
\hline Fuse & 44.69 & 0.00 & 31.1 & 99.7 & 3.71 & $895 \pm 2$ \\
\hline
\end{tabular}

Plateau age $\left(1150^{\circ} \mathrm{C}\right.$-Fuse $)=893 \pm 2 \mathrm{Ma}$

\begin{tabular}{|c|c|c|c|c|c|c|}
\hline 750 & 52.48 & 0.07 & 1.1 & 96.0 & 0.16 & pite; $J=0.014525$ \\
\hline 850 & 52.69 & 0.02 & 4.1 & 98.7 & 0.58 & $1025 \pm 3$ \\
\hline 1050 & 55.42 & $<0.01$ & 51.6 & 99.8 & 7.22 & $1065 \pm$ \\
\hline 1250 & 57.24 & $<0.01$ & 36.2 & 99.9 & 5.08 & $1092 \pm$ \\
\hline Fuse & 56.89 & 0.01 & 6.9 & 99.6 & 0.97 & $1087 \pm$ \\
\hline \multicolumn{7}{|c|}{ Total gas age $=1074 \mathrm{Ma}$} \\
\hline \multicolumn{7}{|c|}{ MC88-8 Phlogopite; $\mathrm{J}=0.014516 ; \mathrm{wt}=0.0378 \mathrm{~g}$} \\
\hline 850 & 46.58 & 0.11 & 1.1 & 93.7 & 0.13 & $932 \pm$ \\
\hline 1050 & 51.71 & 0.01 & 24.8 & 99.5 & 2.89 & $1010 \pm$ \\
\hline 1150 & 54.25 & $<0.01$ & 34.1 & 99.9 & 3.96 & $1048 \pm$ \\
\hline 1250 & 54.72 & $<0.01$ & 34.6 & 99.8 & 4.03 & $1055 \pm$ \\
\hline Fuse & 54.54 & $<0.01$ & 5.3 & 99.4 & 0.62 & $1052 \pm$ \\
\hline
\end{tabular}

Total gas age $=1040 \mathrm{Ma}$

$\begin{array}{cccr}\text { GO-12 Muscovite; } \mathrm{J}=0.014474 ; \mathrm{wt}=0.0369 \mathrm{~g} & \\ 850 & 58.67 & 0.01 & 15.9 \\ 1050 & 57.83 & <0.01 & 48.4 \\ 1150 & 59.78 & <0.01 & 21.0 \\ 1250 & 60.45 & <0.01 & 12.4 \\ \text { Fuse } & 61.14 & <0.01 & 2.3\end{array}$


Table 4. (continued)

\begin{tabular}{|c|c|c|c|c|c|c|}
\hline $\mathrm{T}\left({ }^{\circ} \mathrm{C}\right)$ & ${ }^{40} \mathrm{Ar} /{ }^{39} \mathrm{Ar}$ & $\begin{array}{l}{ }^{36} \mathrm{Ar} /{ }^{39} \mathrm{Ar} \\
\left(\times 10^{-2}\right)\end{array}$ & $\begin{array}{l}{ }^{39} \mathrm{Ar}_{\mathrm{K}} \\
(\% \text { of } \\
\text { total })\end{array}$ & $\begin{array}{l}{ }^{40} \mathrm{Ar}_{\mathrm{R}} \\
(\% \text { of } \\
\text { total })\end{array}$ & $\begin{array}{l}{ }^{39} \mathrm{Ar}_{\mathrm{K}} \\
\left(\times 10^{-12}\right. \\
\text { moles })\end{array}$ & $\begin{array}{l}\text { Apparent } \\
\text { Age (Ma) }\end{array}$ \\
\hline \multicolumn{7}{|c|}{ WI-1A Phlogopite; $J=0.014408 ; \mathrm{wt}=0.0369 \mathrm{~g}$} \\
\hline 850 & 51.61 & 0.06 & 3.5 & 96.7 & 0.48 & $1003 \pm 3$ \\
\hline 1050 & 51.88 & $<0.01$ & 32.4 & 100.0 & 4.47 & $1007 \pm 3$ \\
\hline 1150 & 52.34 & $<0.01$ & 31.0 & 99.3 & 4.26 & $1014 \pm 3$ \\
\hline 1250 & 53.14 & $<0.01$ & 28.6 & 99.9 & 3.94 & $1026 \pm 2$ \\
\hline Fuse & 53.70 & 0.02 & 4.6 & 99.2 & 0.63 & $1034 \pm 4$ \\
\hline \multicolumn{7}{|c|}{ Total gas age $=1016 \mathrm{Ma}$} \\
\hline \multicolumn{7}{|c|}{ WI-1B Phlogopite; $\mathrm{J}=0.014515 ;$ wt $=0.0383 \mathrm{~g}$} \\
\hline 850 & 40.19 & 0.25 & 1.0 & 84.3 & 0.13 & $829 \pm 17$ \\
\hline 1050 & 44.35 & 0.01 & 13.0 & 99.4 & 1.78 & $897 \pm 2$ \\
\hline 1150 & 44.49 & $<0.01$ & 19.1 & 99.8 & 2.62 & $899 \pm 2$ \\
\hline 1250 & 44.80 & $<0.01$ & 38.6 & 100.0 & 5.29 & $904 \pm 3$ \\
\hline Fuse & 44.79 & $<0.01$ & 28.3 & 99.8 & 3.89 & $904 \pm 2$ \\
\hline \multicolumn{7}{|c|}{ Total gas age $=901 \mathrm{Ma}$} \\
\hline Plateau & -Fuse) $=$ & $\mathrm{Ma}$ & & & & \\
\hline
\end{tabular}
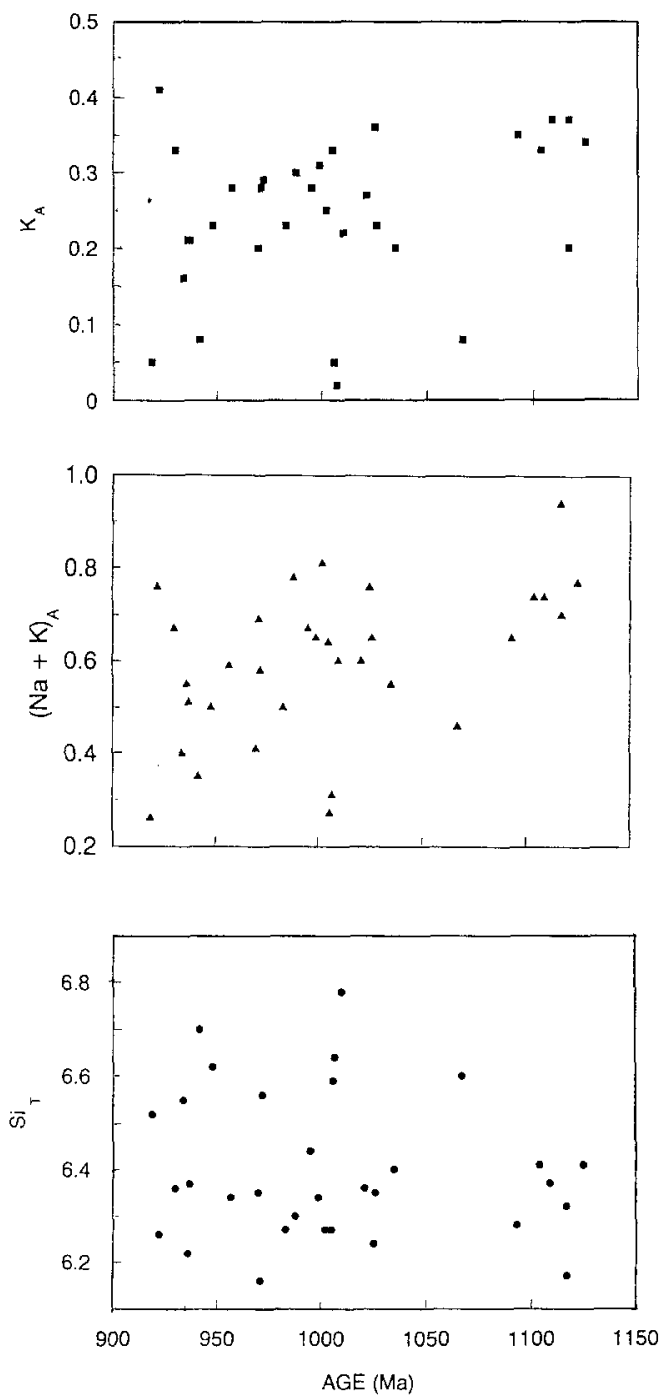

Fig. 4. Plots of elemental occupancies in the tetrahedral (T) and $A$ sites of hornblende versus age. Data are from this study and from Cosca et al. (1991a; 1991b)

\section{Interpretation of results}

The Grenville Orogen in Ontario cooled from temperatures of $\sim 500^{\circ} \mathrm{C}$ down to $\sim 150^{\circ} \mathrm{C}$ at a rate of $1^{\circ}-4^{\circ} \mathrm{C} / \mathrm{Ma}$ (Cosca et al. 1991a). Though some areas began to cool earlier than others as evidenced by the range of ${ }^{40} \mathrm{Ar} /{ }^{39} \mathrm{Ar}$ mineral ages (Fig. 6), the rate of cooling, as determined from coexisting minerals with differing Ar closure temperatures, was nearly constant throughout the Grenville Orogen in Ontario. Based on the cooling rate inferred from the ${ }^{40} \mathrm{Ar} /{ }^{39} \mathrm{Ar}$ age data and an inferred retrograde $\mathrm{P}-\mathrm{T}$ path from the CGB, unroofing of the orogen has been calculated to be 0.03 to $0.14 \mathrm{~km} / \mathrm{Ma}$ (Cosca et al. 1991a).

A variation of over $200 \mathrm{Ma}$ in hornblende ${ }^{40} \mathrm{Ar} /{ }^{39} \mathrm{Ar}$ cooling ages occurs between the Frontenac and the Elzevir terranes of the CMB. Most of the age variation occurs across narrow shear zones which separate the terranes (Fig. 7). In addition, a significant variation in hornblende ${ }^{40} \mathrm{Ar} /{ }^{39} \mathrm{Ar}$ age occurs within Elzevir terrane near the boundary with the Hastings metamorphic low (Carmichael et al. 1978), where rocks with hornblende ${ }^{40} \mathrm{Ar} /{ }^{39} \mathrm{Ar}$ cooling ages of $\sim 935 \mathrm{Ma}$ lie to the east outside the metamorphic low, and rocks with hornblende ${ }^{40} \mathrm{Ar} /{ }^{39} \mathrm{Ar}$ cooling ages of $\sim 1010 \mathrm{Ma}$ lie to the west within the Hastings metamorphic low. Because the nearly constant cooling rates calculated across the CMB argue against multiple metamorphisms causing these variations in age (Cosca et al. 1991a) it is possible that these data indicate a previously undocumented and perhaps tectonically important shear zone within the Elzevir terrane (Fig. 7).

The combined ${ }^{40} \mathrm{Ar} /{ }^{39} \mathrm{Ar}$ data set might suggest that these terranes experienced separate metamorphic histories and that these (allocthonous) terranes were assembled after these rocks cooled below argon closure. Alternatively, because of the consistent pattern of older hornblende ${ }^{40} \mathrm{Ar} /{ }^{39} \mathrm{Ar}$ cooling ages on the southeastern side of all major terrane and tectonic boundaries, together with 

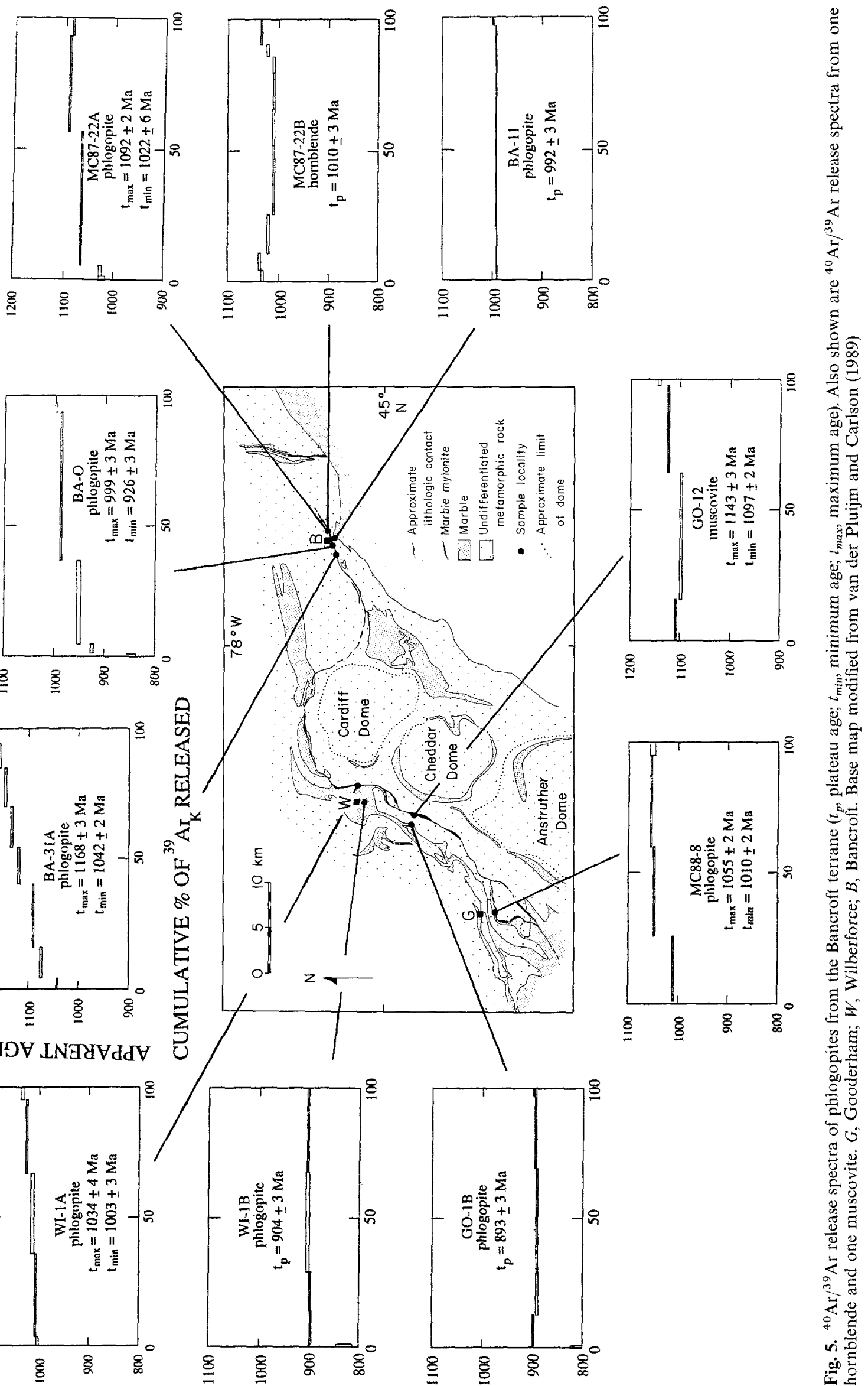


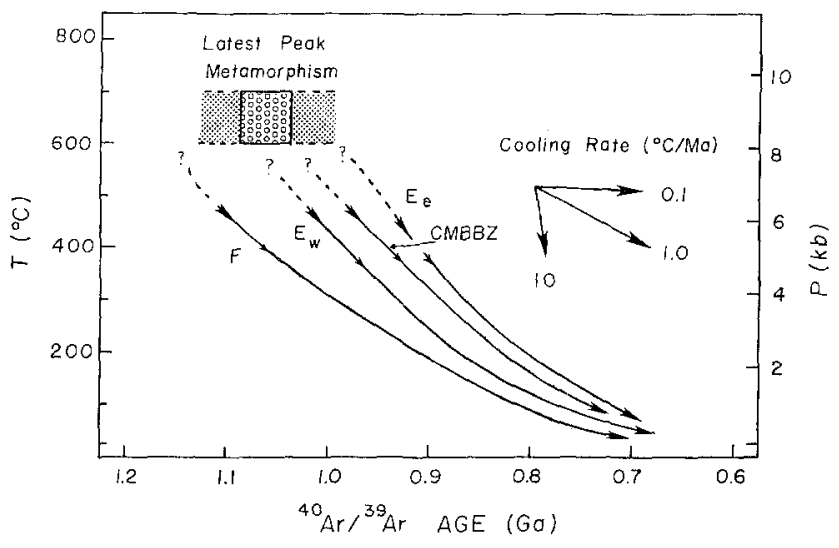

Fig. 6. Summary temperature (T) -time (t)-pressure (P) diagram for terranes of the Central Metasedimentary Belt. $F$, Frontenac terrane; $E_{w}$ and $E_{e}$, the western and eastern Elzevir terrane, respectively; $C M B B Z$, the Central Metasedimentary Belt Boundary Zone

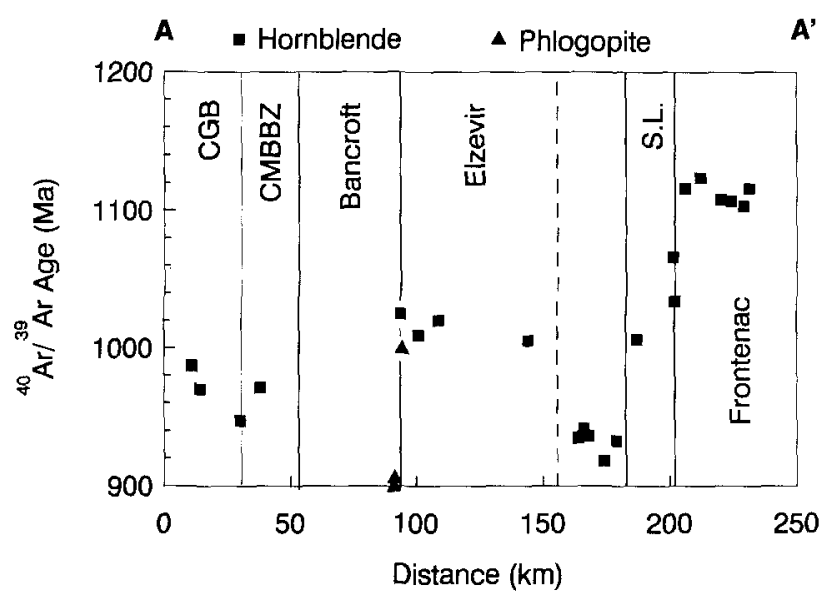

Fig. 7. Plot of hornblende and geologically meaningful phlogopite ${ }^{40} \mathrm{Ar} /{ }^{39} \mathrm{Ar}$ plateau age vs distance across the CMB projected onto the cross section line A-A' of Fig. 3. Solid vertical lines represent positions of terrane boundaries. The dashed vertical line indicates the possible position of a previously unrecognized, tectonically important shear zone

the fact that these boundaries coincide with areas of high strain and some show evidence for superimposed extensional shear, we interpret the age pattern in Fig. 7 to be a consequence of differential uplift during extensional deformation during the later stages of cooling following orogenesis.

Viewed within a geologic time frame, an instantaneous doubling of crustal thickness (e.g. $70 \mathrm{~km}$ ), produced for example by rapid thrusting, requires less than $20 \mathrm{Ma}$ for the subsequent thermal relaxation of crustal isotherms disturbed during thrusting (e.g. England and Thompson 1984). Because the Grenville Orogen experienced a protracted period of uniformly slow cooling and unroofing (Cosca et al. 1991a), at least below temperatures of argon closure, it can be assumed that the regional distribution of isotherms, averaged over the same period of cooling, was roughly parallel to the paleotopography. By assuming that the regional isotherms were roughly parallel to topo- graphy, no consideration is given to local sources of heat production, for example, intrusive bodies and their influence on the regional isotherms. Although such heat sources were obviously present in the Grenville (e.g. Holm et al. 1986; Corriveau 1990; Corriveau et al. 1990), the nearly constant rate of cooling, calculated from many coexisting mineral ${ }^{40} \mathrm{Ar} /{ }^{39} \mathrm{Ar}$ ages collected over a wide area (Cosca et al. 1991a), suggests that such heat sources were probably sufficiently cold by the time these rocks cooled below argon closure that they did not greatly affect the argon systematics of the samples analyzed. Thus, if the entire orogen was uniformly unroofed as a more or less rigid block during this period of cooling, the ${ }^{40} \mathrm{Ar} /{ }^{39} \mathrm{Ar}$ cooling ages for each mineral, for example hornblendes, should be approximately the same. The large variation in hornblende ${ }^{40} \mathrm{Ar} /{ }^{39} \mathrm{Ar}$ cooling ages from across the $\mathrm{CMB}$, however, indicates that unroofing of this region was nonuniform.

Although less is known about the argon systematics of phlogopite than that of hornblende or even biotite, the well developed plateaus and reasonable ${ }^{40} \mathrm{Ar} /{ }^{39} \mathrm{Ar}$ ages suggest that phlogopites from the undeformed marbles (WI-1B, GO-1B, BA-11) are recording reliable cooling ages. Thus, the marble to the southeast of the mylonite zone (BA-11, $992 \pm 3 \mathrm{Ma}$ ) apparently cooled through argon closure $\sim 100 \mathrm{Ma}$ before marble to the northwest of the mylonite zone (WI-1B, $904 \pm 3 \mathrm{Ma}$; GO-1B, 893 $\pm 3 \mathrm{Ma}$ ). In contrast, all phlogopites and one muscovite collected from within the shear zone have highly variable ${ }^{40} \mathrm{Ar} /{ }^{39} \mathrm{Ar}$ ages and monotonically increasing ${ }^{40} \mathrm{Ar} /{ }^{39} \mathrm{Ar}$ profiles. Many of the micas from the shear zones actually show older ${ }^{40} \mathrm{Ar} /{ }^{39} \mathrm{Ar}$ ages than the unsheared micas, and have probably incorporated extraneous argon, even though they exhibit argon isotopic profiles seemingly consistent with diffusional loss of radiogenic argon. Based on geologicl considerations, the excess argon was probably incorporated into the phlogopites during a period of active shearing when the shear zone was charged with volatile-bearing fluids containing extraneous argon. In addition, petrographic observations of sheared marble reveal that many of the individual phlogopite grains have been folded and rotated during deformation and many display anomalous birefringence when viewed under polarized light. Electron microprobe analyses indicate no detectable chlorite, but small amounts of alteration to a clay mineral with a basal spacing of 19 angstroms was identified by powder X-ray diffraction in one sample.

These observations collectively suggest the likely incorporation of excess argon in the sheared samples. This interpretation is further supported by a geological field experiment in which two samples were collected from the same outcrop (MC87-22A; B), a sheared phlogopite from marble, and a hornblende from an amphibolite lens within the marble. The phlogopite yielded an ${ }^{40} \mathrm{Ar} /{ }^{39} \mathrm{Ar}$ total gas age of $1074 \mathrm{Ma}$ while the hornblende yielded an ${ }^{40} \mathrm{Ar} /{ }^{39} \mathrm{Ar}$ plateau age of $1010 \pm 3 \mathrm{Ma}$. While the hornblende forms a plateau at $1010 \mathrm{Ma}$, the somewhat saddleshaped spectrum and slightly lower radiogenic yields during the first and last laboratory heating steps indicate the possibility of excess argon. Therefore, the $1010 \mathrm{Ma}$ age for the hornblende can be interpreted as a maximum age for the shearing event. Accepting a maximum cooling age 
of $1010 \mathrm{Ma}$ would therefore require that the phlogopite has a significantly higher Ar closure temperature than hornblende. However, based on the observations that every phlogopite collected in sheared marbles has anomalously high ${ }^{40} \mathrm{Ar} /{ }^{39} \mathrm{Ar}$ ages and displays petrographic evidence of deformation, the results from the field experiment suggest that this phlogopite, and all sheared phlogopites, incorporated excess argon during shearing (extension) in the mylonite zone. Easton and Roddick (1988) have also noted excess argon in biotite from the CMBBZ

The phlogopites collected from unsheared marbles on either side of the extensional Bancroft shear zone, like the hornblende data, display a similar pattern of older ages to the southeast, in this case a difference of $\sim 100 \mathrm{Ma}$. This observation, assuming a regional cooling rate of $2^{\circ} \mathrm{C} / \mathrm{Ma}$ and a $30^{\circ} \mathrm{C} / \mathrm{km}$ retrograde path, suggests post phlogopite closure extensional displacement of $\sim 7 \mathrm{~km}$, which is of the same order of magnitude as that inferred by van der Pluijm and Carlson (1989) $(5-6 \mathrm{~km})$ based on other geologic constraints. However, when considering the hornblende ${ }^{40} \mathrm{Ar} /{ }^{39} \mathrm{Ar}$ data broadly across the Bancroft shear zone, that is comparing the hornblendes in the western Elzevir terrane with those of the CMBBZ and the eastern CGB (Fig. 7) a much smaller variation is observed, approximately $50 \mathrm{Ma}$, suggesting that perhaps the displacement was much smaller over a wider area. In any case more data are needed in the vicinity of the shear zone to argue any interpretation more convincingly.

\section{Tectonic implications}

Geochemical evidence is mounting to suggest that parts of the $\mathrm{CMB}$ evolved in an island arc environment while other parts may have been assembled into their approximate positions by terrane accretion (e.g. Davidson 1986; Corriveau 1990). The large, highly strained shear zones separating the terranes of the CMB must be considered strong candidates for ancient suture zones in such a scenario. Field relationships clearly indicate that these shear zones, in addition to smaller shear zones within the terranes, were zones of northwest directed ductile thrusting of a regional scale and similar to those that have been observed in the CMBBZ and in the high-grade gneisses of the CGB. There are as yet insufficient data to say with confidence when many of the shear zones within the CMB were active as zones of compression. In one such shear zone, ${ }^{40} \mathrm{Ar} /{ }^{39} \mathrm{Ar}$ hornblende cooling ages of $\sim 1110 \mathrm{Ma}$ are preserved on either side of the Perth Road mylonite in the Frontenac terrane (Fig. 2). Therefore, any significant displacement along this zone is likely to have occurred prior to $1110 \mathrm{Ma}$, probably during a period of compression. Later, significant compressional events occurred in various parts of the CMBBZ at $\sim 1060 \mathrm{Ma}$ with minor thrusting possibly as late as $1030-1000 \mathrm{Ma}$ (van Breemen and Hanmer 1986; McEachern et al. 1990). Late southeast-directed extensional displacements are interpreted to have occurred following the major northwest, compression-dominated, orogenic phases of the Grenvillian Orogeny, and, consistent with field relationships, probably occurred along previous zones of thrusting.
The difference in temperature at $919 \mathrm{Ma}$, between rocks containing the oldest (1125 Ma) and youngest hornblende (919 Ma) may be calculated given a regional cooling rate. The burial depth of those rocks may then be calculated by applying a model retrograde P-T path of $30^{\circ} \mathrm{C} / \mathrm{km}$ for temperatures below $500^{\circ} \mathrm{C}$ (Cosca et al. 1991a). The calculated depths across the CMB to which these rocks were buried $\sim 919 \mathrm{Ma}$ (with a regional cooling rate of $2 \% \mathrm{Ma}$ ) is illustrated in Fig. 8 for the transect $\mathrm{A}-\mathrm{A}^{\prime}$ (Fig. 3) indicating that rocks now at the surface were buried from 3 to $17 \mathrm{~km}$. The average unroofing rate calculated assuming this regional cooling rate and model P-T path is therefore $0.07 \mathrm{~km} / \mathrm{Ma}$. Because these rocks are now at the same burial depth (i.e. at the surface) a minimum of $14 \mathrm{~km}$ of differential unroofing must have occurred within the CMB between the Frontenac and Elzevir terranes sometime after $919 \mathrm{Ma}$.

Where preserved in the $\mathrm{CMB}$, the Proterozoic metamorphic rocks are unconformably overlain by flat-lying Cambrian sandstones and Ordovician limestones. This observation requires that the $\mathrm{CMB}$ was eroded and exposed at sea level by $\sim 600 \mathrm{Ma}$. Therefore, differential unroofing in the $\mathrm{CMB}$ is confined to the time period between $\sim 919$ and $\sim 600 \mathrm{Ma}$, but the duration of differential unroofing was probably confined to a narrower interval of time. The $14 \mathrm{~km}$ of differential unroofing inferred for the area between Frontenac and Elzevir terranes thus requires a minimum average unroofing rate of $0.05 \mathrm{~km} / \mathrm{Ma}$ during this interval, but it probably occurred more rapidly.

Speculation that rocks from the CMB in Ontario may have a similar parentage and tectonic history to rocks of the Adirondack Lowlands in New York is based on similarities in lithology, metamorphic grade, and age relations (e.g. deLorraine and Carl 1986; McLelland and Isachsen 1986; McLelland et al. 1988; Carl et al. 1990; Daly and McLelland 1991). Additional evidence in support of a similar tectonometamorphic history is contained.

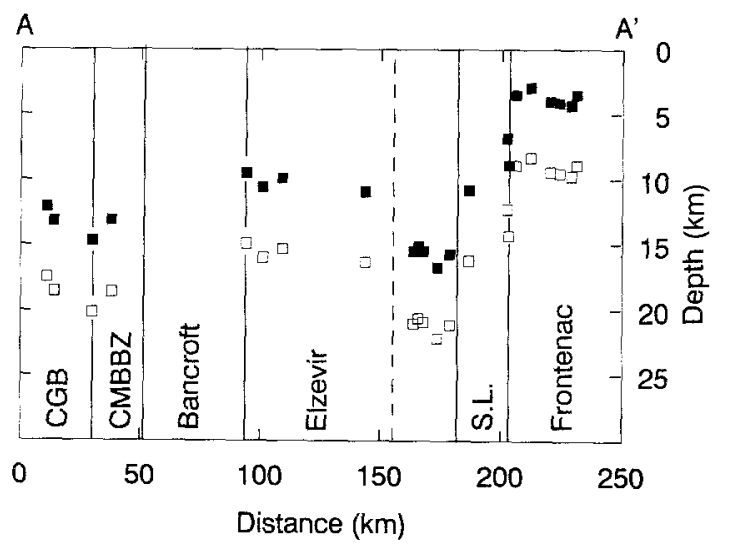

Fig. 8. Modeled burial depth of exposed rocks in the CMB $\sim 919 \mathrm{Ma}$ (solid squares) projected onto cross section line $\mathrm{A}-\mathrm{A}^{\prime}$ of Fig. 3. For comparsion, the calculated depths of these rocks at 1000 Ma are similarly calculated (open squares); above temperatures of $500^{\circ} \mathrm{C}$ a retrograde P-T path of $20^{\circ} \mathrm{C} / \mathrm{km}$ (Anovitz and Essene 1990) is assumed, and in addition, a cooling rate of $1.34^{\circ} \mathrm{C} / \mathrm{Ma}$ is necessary in order to sustain a constant unroofing rate of $0.07 \mathrm{~km} / \mathrm{Ma}$ throughout the rock column. 
in the hornblende ${ }^{40} \mathrm{Ar} /{ }^{39} \mathrm{Ar}$ ages together with the $\mathrm{U} / \mathrm{Pb}$ sphene ages of 1134 to $1105 \mathrm{Ma}$ for the Adirondack Lowlands that have been reported by Rawnsley et al. (1987). These ages overlap the older ${ }^{40} \mathrm{Ar} /{ }^{39} \mathrm{Ar}$ hornblende ages from the Frontenac terrane. Rawnsley et al. (1987) interpret the sphene ages as cooling ages through closure to $\mathrm{Pb}$ diffusion, which they estimate at $500^{\circ}-550^{\circ} \mathrm{C}$. Because this closure temperature is similar to that for $\mathrm{Ar}$ closure in slowly cooled hornblendes $\left(\sim 480^{\circ} \mathrm{C}\right.$; Harrison 1981), a similar cooling history is implied. A test of this hypothesis is the subject of additional work in progress based on ${ }^{40} \mathrm{Ar} /{ }^{39} \mathrm{Ar}$ analyses of hornblendes from the Adirondack Lowlands and the Frontenac terrane.

\section{Discussion}

While tectonic accretion of allochthonous terranes cannot be ruled out as an explanation for the variation in ${ }^{40} \mathrm{Ar} /{ }^{39} \mathrm{Ar}$ age data in the CMB we currently interpret the pattern of ${ }^{40} \mathrm{Ar} /{ }^{39} \mathrm{Ar}$ ages in the CMB to be an artifact of post-orogenic extension. From the variations in hornblende and selected phlogopite ${ }^{40} \mathrm{Ar} /{ }^{39} \mathrm{Ar}$ cooling ages it is interpreted that extension was active along all major tectonic boundaries within the CMB by $\sim 900 \mathrm{Ma}$. The large amount $(\sim 14 \mathrm{~km})$ of post $900 \mathrm{Ma}$ differential unroofing required in the eastern part of the CMB indicates that active zones of extension may have migrated to the southeast with time. Although more data are necessary for confirmation, an overall southeast migration of earlier, active zones of regional thrusting has already been proposed (Davidson 1986) in addition to a southeast migration of an ancient subduction zone (Corriveau 1990). Extension within the Grenville Orogen in the CMB ceased before, possibly well before, $\sim 600 \mathrm{Ma}$, by which time the present structural levels were exposed and sedimentary rocks were beginning to be deposited upon them at or near sea level.

The formation of these late extensional shear zones in the CMB may have been caused by gravitational instability developed after a period of uncompensated crustal thickening (Dewey 1988). Such extensional shear zones are observed in the Himalaya (Burchfiel and Royden 1985), and analogous processes may have occurred during the late tectonic evolution of the Grenville Orogen (Dewey and Burke 1973; Davidson et al. 1982; Windley 1986; Hanmer 1988; van der Pluijm and Carlson 1989). This suggests that plate tectonic processes that have been dominating earth history in Phanerozoic times were also operating in Proterozoic orogens.

Acknowledgments. This paper was improved by the discussions and reviews of R Haugerud, K Mezger, D Milton, ZD Sharp, R Sliney, and BA van der Pluijm. Thanks are due to BA van der Pluijm for providing several samples and to RM Easton for providing unpublished tectonic maps of the CMB. A particularly constructive journal review by $W$ Hames clarified the text as did that of an anonymous reviewer. The research was supported by NSF grants EAR 84-08169, 88-05083, and 89-03805.

\section{References}

Anovitz LA, Essene EJ (1990) Thermobarometry and pressuretemperature paths in the Grenville Province of Ontario. J Petrol 31: 197-241

Ayres LD, Lumbers SB, Milne VG, Robeson DW (1971) Ontario geological map 2197. Scale 1:1,013,760.

Baer AJ (1976) The Grenville Province in Helikian times: a possible model of evolution. Phil Trans R Soc London 280:499-515

Baldwin SL, Harrison TM, FitzGerald JD (1990) A diffusion of ${ }^{40} \mathrm{Ar}$ in metamorphic hornblende. Contrib Mineral Petrol $105: 691-703$

Bell K, Blenkinsop J (1980) Whole rock $\mathrm{Rb} / \mathrm{Sr}$ studies in the Grenville Province of southeastern Ontario and western Quebec-a summary report. Geol Surv Can Pap 80-1C:152-154

Burchfiel BC, Royden LH (1985) North-south extension within the convergent Himalayan region. Geology 13:679-682

Carl JD, deLorraine WF, Mose DG, Shieh YN (1990) Geochemical evidence for a revised Precambrian sequence in the northwest Adirondacks, New York. Geol Soc Am Bull 102:182-192

Carlson KA, van der Pluijm BA, Hanmer S (1990) Marble mylonites of the Bancroft shear zone: evidence for crustal extension in the Canadian Grenville. Geol Soc Am Bull 102:174-181

Carmichael DM, Moore JM Jr, Skippen GB (1978) Isograds around the Hastings metamorphic "low". In: Currie AL, Mackasey WO (eds) Toronto '78 Field Trip Guidebook. Geol Assoc Canada, Waterloo, Ontario, pp 325-346

Carmichael DM, Helmstaedt HH, Thomas N (1987) A field trip in the Frontenac Arch with emphasis on stratigraphy, structure and metamorphism. In: Friends of the Grenville Field Trip Guidebook. Queen's University, Kingston, Ontario, 24pp

Corriveau L (1990) Proterozoic subduction and terrane amalgamation in the southwestern Grenville province, Canada: evidence from ultrapotassic to shoshonitic plutonism. Geology $18: 614-617$

Corriveau L, Heaman LM, Marcantonio F, van Breeman O (1990) $1.1 \mathrm{Ga}$ K-rich alkaline plutonism in the SW Grenville Province. Contrib Mineral Petrol 105:473-485

Cosca MA, Sutter JF, Essene EJ (1991a) Cooling and inferred uplift/erosion history of the Grenville Orogen, Ontario: constraints from ${ }^{40} \mathrm{Ar} /{ }^{39} \mathrm{Ar}$ thermochronology. Tectonics 10:959-977

Cosca MA, Essene EJ, Bowman JR (1991b) Major element, $\mathrm{FeO} / \mathrm{Fe}_{2} \mathrm{O}_{3}$, and $\mathrm{H}_{2} \mathrm{O}$ measurements of metamorphic hornblendes: implications for amphibole normalizations and calculated metamorphic $\mathrm{H}_{2} \mathrm{O}$ activities. Contrib Mineral Petrol $108: 472-484$

Culshaw NG, Davidson A, Nadeau L (1983) Structural subdivisions of the Grenville Province in the Parry Sound-Algonquin region, Ontario. Geol Surv Can Pap 79-1B: 155-163

Dalrymple GB, Alexander EC, Lanphere MA, Kraker GP (1981) Irradiation of samples for ${ }^{40} \mathrm{Ar} /{ }^{39} \mathrm{Ar}$ dating using the Geological Survey TRIGA reactor. US Geol Surv Prof Pap 1176

Daly JS, McLelland JM (1991) Juvenile Middle Proterozoic crust in the Adirondack Highlands, Grenville province, northeastern North America. Geology 19:119-122

Davidson A (1984) Identification of ductile shear zones in the southwestern Grenville Province of the Canadian Shield. In: Kroner A, Greiling R (eds) Precambrian Tectonics Illustrated, E. Schweizerbart'sche Verlagsbuchhandlung, Stuttgart, pp 263-279

Davidson A (1986) New interpretations in the southwestern Grenville Province. Geol Assoc Can Spec Pap 31:61-74

Davidson A, Culshaw NG, Nadeau L (1982) A tectonometamorphic framework for part of the Grenville Province, Parry Sound region, Ontario. Geol Surv Can Pap 82-1A : 175-190

Davis DW, Barlett JR (1988) Geochronology of the Belmont Lake Metavolcanic Complex and implications for crustal development in the Central Metasedimentary Belt, Grenville Province, Ontario. Can J Earth Sci 25:1751-1759

deLorraine W, Carl JD (1986) Precambrian stratigraphy of the northwest Adirondacks. In: Friends of the Grenville Field Trip Guidebook. Queen's University, Kingston, Ontario, 37pp 
Dewey JF (1988) Extensional collapse of orogens. Tectonics 7:1123-1139

Dewey JF, Burke KCA (1973) Tibetan, Variscan and Precambrian basement reactivation: products of continental collision. J Geol $81: 683-692$

Easton RM (1988) Regional mapping and stratigraphic studies, Grenville Province with some notes on mineralization environments. Ontario Geol Surv Misc Pap 141:300-308

Easton RM (1989) Regional mapping and stratigraphic studies, Grenville Province. Ontario Geol Surv Misc Pap 146: 153-157

Easton RM, Bartlett JR (1984) Precambrian geology of the Howland area, Haliburton, Peterborough and Victoria Counties. Ont Geol Surv Prelim Map P 2699, Geol Ser

Easton RM, Roddick JC (1988) K/Ar ages from the Minden area, Grenville Province, Ontario. Geol Surv Can Pap 88-2:41-44

England PC, Thompson AB (1984) Pressure-temperature-time paths of regional metamorphism I: Heat transfer during the evolution of regions of thickened continental crust. J Petrol 25:894-928

Giletti BJ (1974) Studies in diffusion I: Ar in phlogopite mica. Carnegie Inst Washington Publ 634:107-115

Hanes JA, Clark SJ, Archibald DA (1988) $\mathrm{An}{ }^{40} \mathrm{Ar} /{ }^{39} \mathrm{Ar}$ geochronological study of the Elzevir batholith and its bearing on the tectonothermal history of the southwestern Grenville Province, Canada. Can J Earth Sci 25: 1834-1845

Hanmer SK (1988) Ductile thrusting at mid-crustal level, southwestern Grenville Province. Can J Earth Sci 25:1049-1059

Hanmer SK, Ciesielski A (1984) Structural reconnaissance of the northwest boundary of the Central Metasedimentary Belt, Grenville Province, Ontario and Quebec. Geol Surv Can Pap 841B: $121-131$

Hanmer SK, Thivierge RH, Henderson JR (1985) Anatomy of a ductile thrust zone: part of the northwest boundary of the Central Metasedimentary Belt, Grenville Province, Ontario. Geol Surv Can Pap 85-1B : 1-5

Harrison TM (1981) Diffusion of ${ }^{40} \mathrm{Ar}$ in hornblende. Contrib Mineral Petrol 78:324-331

Harrison TM, Duncan IJ, McDougall I (1985) Diffusion of ${ }^{40} \mathrm{Ar}$ in biotite: temperature, pressure and compositional effects. Geochim Cosmochim Acta 49:2461-2468

Haugerud RA, Kunk MJ (1988) ArAr* a computer program for reduction of ${ }^{40} \mathrm{Ar} /{ }^{39} \mathrm{Ar}$ data. US Geol Surv Open File Rep $88-261$

Heaman LM, McNutt RH, Krogh TE (1986) Geological significance of $\mathrm{U} / \mathrm{Pb}$ and $\mathrm{Rb} / \mathrm{Sr}$ ages for two pre-tectonic granites from the Central Metasedimentary Belt, Ontario. Geol Assoc Can Spec Pap 31:209-221

Holm PE, Smith TE, Huang CH, Gerasimoff M, Grant B, McLaughilin K (1986) Geochemistry of metavolcanic rocks and dykes from the Central Metasedimentary Belt, Grenville Province, southeastern Ontario. Geol Assoc Can Spec Pap 31:255-269

Lonker SW (1980) Conditions of metamorphism in high-grade pelitic gneisses from the Frontenac Axis, Ontario, Canada. Can J Earth Sci 17: 1666-1686

Marcantonio F, McNutt RH, Dickin AP, Heaman LM (1990) Isotopic evidence for the crustal evolution of the Frontenac Arch in the Grenville Province of Ontario, Canada. Chem Geol $83: 297-314$

McEachern SJ, Hanmer S, van Breemen O (1990) Structure and geochronology of the Central Metasedimentary Belt boundary thrust zone, Pembroke, Ontario. Geol Soc Am Abstr Prog 22:54

McLelland JM, Isachsen YW (1986) Synthesis of geology of the Adirondack Mountains, New York, and their tectonic setting within the southwestern Grenville Province. Geol Assoc Can Spec Pap 31:75-94
McLelland JM, Lochhead A, Vyhnal C (1988) Evidence for multiple metamorphic events in the Adirondack Mountains, N. Y. J Geol $96: 279-298$

Mezger K, Bohlen SR, Essene EJ, van der Pluijm BA, Halliday AN (1990) Metamorphic history of the Grenville Terrane of Southern Ontario and New York. Geol Soc Am Abstr Prog 22:56

Moecher DP, Essene EJ, Anovitz LM (1988) Calculation and application of clinopyroxene-plagioclase-quartz geobarometers. Contrib Mineral Petrol 100:92-106

Moore JM Jr (1982) Stratigraphy and tectonics of the Grenvillian Orogen in eastern Ontario. Ottawa-Carleton Centre for Geoscience Studies, Grenville Workshop Prog and Abs, $p 7$

Moore JM Jr (1986) Introduction: the 'Grenville Problem' then and now. Geol Assoc Can Spec Pap 31:1-11

Moore JM Jr, Thompson PH (1980) The Flinton Group: a late Precambrian metasedimentary succession in the Grenville Province of eastern Ontario. Can J Earth Sci 17:1685-1707

Rawnsley CM, Bohlen SR, Hanson GN (1987) Constraints on the cooling history of the Adirondack Mtns: U/Pb investigation of metamorphic sphene. EOS Trans Am Geophys Union 68:1515

Rivers T, Martingole J, Gower CF, Davidson A (1989) New tectonic divisions of the Grenville Province, southeast Canadian Shield. Tectonics $8: 63-84$

Samson SD, Alexander EC (1987) Calibration of the interlaboratory ${ }^{40} \mathrm{Ar} /{ }^{39} \mathrm{Ar}$ dating standard, MMhb-1. Chem Geol Isot Geosci Sec $66: 27-34$

Silver LT, Lumbers SB (1966) Geochronologic studies in the Bancroft-Madoc area of the Grenville Province, Ontario. Geol Soc Am Abstr Prog 87:156

Steiger RH, Jäger E (1977) Subcommission on Geochronology: convention on the use of decay constants in geo- and cosmochronology. Earth Planet Sci Lett 36:359-362

Stockwell CH (1964) Fourth report on structural provinces, orogenies, and time-classification of rocks of the Canadian Precambrian Shield. Geol Surv Can Pap 64-17 (Part II) 1-21

van Breemen O, Davidson A (1988) U-Pb zircon ages of granites and syenites in the Central Metasedimentary Belt, Grenville Province, Ontario. Geol Surv Can Pap 88-2 45-50

van Breemen O, Davidson A (1990) U-Pb zircon and baddeleyite ages from the Central Gneiss Belt, Ontario. Geol Surv Can Pap $89-285-92$

van Breemen O, Hanmer SK (1986) Zircon morphology and U/Pb geochronology in active shear zones: studies on syntectonic intrusions along the northwest boundary of the Central Metasedimentary Belt, Grenville Province, Ontario. Geol Surv Can Pap 86-1B : 775-784

van Breemen O, Davidson A, Loveridge WD, Sullivan RW (1986) $\mathrm{U}-\mathrm{Pb}$ zircon geochronology of Grenville tectonites, granulites, and igneous precursors, Parry Sound, Ontario Geol Assoc Can Spec Pap 31:191-207

van der Pluijm BA, Carlson KA (1989) Extension in the Central Metasedimentary Belt of the Ontario Grenville: timing and tectonic significance. Geology 17:161-164

Windley BF (1986) Comparative tectonics of the western Grenville and the western Himalaya. Geol Assoc Can Spec Pap $31: 341-348$

Woussen G, Roy DW, Dimroth RE, Chown EH (1986) MidProterozoic extensional tectonics in the core zone of the Grenville Province. Geol Assoc Can Spec Pap 31:297-311

Wynne-Edwards HR (1972) The Grenville Province. Geol Assoc Can Spec Pap $11: 263-334$

Editorial responsibility: T. Grove 